\title{
Advances in the Synthesis of Crystalline Metallosilicate Zeolites via Interlayer Expansion
}

\author{
Chaoqun Bian ${ }^{1, * \mathbb{D}}$, Yichang Yang ${ }^{2,3}$, Xiaohui Luo ${ }^{1}$, Wenxia Zhang ${ }^{1}$, Jie Zhang ${ }^{1}$, Longfeng Zhu ${ }^{2, *(\mathbb{D})}$ \\ and Jianping Qiu ${ }^{4}$
}

1 Pharmaceutical and Material Engineering School, Jinhua Polytechnic, Jinhua 321000, China; jhc0579@163.com (X.L.); 0420@163.com (W.Z.); 0579zjzj2@sina.com (J.Z.)

2 College of Biological, Chemical Sciences and Engineering, Jiaxing University, Jiaxing 314001, China; 2112001238@zjut.edu.cn

3 College of Chemical Engineering, Zhejiang University of Technology, Hangzhou 310014, China

4 Xingzhi College, Zhejiang Normal University, Jinhua 321004, China; jipiqi@126.com

* Correspondence: bian00@zju.edu.cn (C.B.); zhulf1988@mail.zjxu.edu.cn (L.Z.); Tel.: +86-579-8226-4066 (C.B.); +86-573-8364-0131 (L.Z.)

Citation: Bian, C.; Yang, Y.; Luo, X.; Zhang, W.; Zhang, J.; Zhu, L.; Qiu, J. Advances in the Synthesis of Crystalline Metallosilicate Zeolites via Interlayer Expansion. Molecules 2021, 26, 5916. https://doi.org/ 10.3390/molecules26195916

Academic Editors: Giuseppe Cirillo and Chongjun Zhao

Received: 2 August 2021

Accepted: 24 September 2021

Published: 29 September 2021

Publisher's Note: MDPI stays neutral with regard to jurisdictional claims in published maps and institutional affiliations.

Copyright: (c) 2021 by the authors. Licensee MDPI, Basel, Switzerland. This article is an open access article distributed under the terms and conditions of the Creative Commons Attribution (CC BY) license (https:// creativecommons.org/licenses/by/ $4.0 /)$.

\begin{abstract}
Given the numerous industrial applications of zeolites as adsorbents, catalysts, and ionexchangers, the development of new zeolite structures is highly desired to expand their practical applications. Currently, a general route to develop new zeolite structures is to use interlayer expansion agents to connect layered silicates. In this review, we briefly summarize the novel zeolite structures constructed from the lamellar precursor zeolites MWW, RUB-36, PREFER, Nu-6(1), COK-5, and PLS-1 via interlayer expansion. The contents of the summary contain detailed experiments, physicochemical characterizations, possible expansion mechanisms, and catalytic properties. In addition, the insertion of metal heteroatoms (such as $\mathrm{Ti}, \mathrm{Fe}, \mathrm{Sn}$ ) into the layered zeolite precursor through interlayer expansion, which could be helpful to modify the catalytic function, is discussed.
\end{abstract}

Keywords: layered silicates; interlayer expansion; zeolites; synthesis; metal heteroatoms insertion

\section{Introduction}

In the past decades, a variety of novel zeolite structures have been synthesized, thus employing the practical application widely in industrial production as adsorbents, catalysts, and ion-exchangers, which has produced great economic benefits [1-4]. The synthesis of zeolite structures with new topologies is of constant interest from the viewpoint of both fundamental research and industrial application s [5-8]. In most cases, three-dimensional (3D) zeolites with 4-connected framework form directly from inorganic precursors assembled in the presence of organic or inorganic structure-directing agents (SDAs) [9-11]. In addition, two-dimensional (2D) layered zeolites with new topological structures, which consist of lamellar sheets because the bridging units between the layers are not connected with four T-atoms but only two, operated by calcination [12], swelling [13,14], delamination [15,16], and interlayer expansion [17-20], are considered as promising catalysts for many catalytic reactions. Table 1 lists published zeolite synthesis via topotactic condensation of layered silicates. The close names of zeolites related to nearly identical materials. These new topological structures not only maintain the basic structural unit of the zeolites but also offer larger pore size and higher specific surface area, making them more suitable for the reaction of molecules of different sizes, thereby broadening the range of available zeolites [21,22].

Interlayer-expansion zeolites (IEZs) usually use silylating agents or metal salt to connect layer silicates to novel 3D frameworks [35-38], which has led to several new microporous zeolite frameworks, such as ferrierite (FER) from PREFER, the MWW-type framework (MWW) from MCM-22 [30,38], COE-3 (CDO) from RUB-36 [39], and COE-5 (MFS) from COK-5 [40]. As the number of microporous zeolite frameworks increases, 
IEZs are gradually forming an important family of microporous materials [41-46]. The silylating agents generally include a single silicon dichlorodimethylsilane (DCDMS), dihydroxydimethylsilane (DHDMS), and diethoxydimethylsilane (DEDMS), and two silicon macromolecular silane reagents 1,2-dichlorotetramethyldisilane $\left(\mathrm{ClMe}_{2} \mathrm{Si}_{-} \mathrm{SiMe}{ }_{2} \mathrm{Cl}\right)$ and 1,3-Dichlorotetramethyldisiloxane $\left(\mathrm{ClMe}_{2} \mathrm{Si}-\mathrm{O}-\mathrm{SiMe}_{2} \mathrm{Cl}\right)$. The silane agents provide a $\mathrm{Si}$ source for the interlayer space with the replacement of the organic SDA. Notably, the insertion of $\mathrm{Si}$ atoms increases the pore size of the original materials, which in turn increases the scope of applications of these materials [44,46-48]. For example, the well-known interlayer expanded MWW-type aluminosilicate has been found to play an important role in the selective production of bulk petrochemicals [31,32,42,48].

Table 1. The published zeolite synthesis via topotactic condensation of layered silicates. Reprinted with permission from ref. [22]. Copyright 2012, Schweizerbart Science Publishers.

\begin{tabular}{cccc}
\hline Layered Silicate & Zeolite & $\begin{array}{c}\text { Zeolite Framework } \\
\text { Type, Degree of Order }\end{array}$ & Reference \\
\hline EU-19 & EU-20 & CAS, disordered & {$[23]$} \\
MCM-65 (as made) & MCM-65 (calcined) & CDO, fair ordered & {$[24]$} \\
PLS-1 & CDS-1 & & {$[25]$} \\
UZM-13, UZM-17, UZM-19 & UZM-25 & CDO, well ordered & {$[26]$} \\
RUB-36, RUB-38, RUB-48 & RUB-37 & & {$[28]$} \\
PLS-4 & $/$ & FER, well ordered & {$[29]$} \\
PREFER & Ferrierite & & {$[28]$} \\
PLS-3 & CDS-3 & MWW, well ordered & {$[30]$} \\
MCM-22 precursor & MCM-22 & MWW, disordered & {$[31]$} \\
ITQ-1 & ITQ-1 (calcined) & NSI, well ordered & {$[15]$} \\
EMM-10-p & EMM-10 & RRO, well ordered & {$[17-19]$} \\
NU-6(1) & Nu-6(2) & RWR, fair ordered & {$[7,20]$} \\
RUB-39 & RUB-41 & SOD, fairly ordered & {$[33]$} \\
RUB-18 & RUB-24 & PCR, well ordered & {$[34]$} \\
RUB-15 & Silica-Sodalite & IPC-4 &
\end{tabular}

In addition, the insertion of metal heteroatoms (such as $\mathrm{Ti}, \mathrm{Fe}, \mathrm{Sn}$ ) has also been reported [47-51], which could be beneficial for modifying the catalytic function. One solution is to add heteroatoms during the synthesis of the precursor. For example, the microporous titanosilicate Ti-COE-4 zeolite is synthesized by interlayer expansion of TiRUB-36 with DHDMS [50]. Another novel synthesis route involves using metal salts is to connect layered silicates instead of normal silylating agents. A typical example of this route is Fe-IEZ-RUB-36, which is synthesized by interlayer expansion of RUB-36 with $\mathrm{FeCl}_{3}$ [51].

For readers not familiar with layered zeolites, only one typical sample in a series of similar layer materials is discussed in this review (RUB-36 $\approx$ PLS- $4 \approx$ UZM-13 and RUB-18 $\approx$ ITQ- $\approx$ MCM-22 $\approx$ EMM-10). Herein, we briefly summarize the novel zeolite structures constructed from the lamellar precursor zeolites MWW, RUB-36, PREFER, Nu-6(1), COK-5, and PLS-1 via interlayer expansion (Table 2). The summary includes a discussion of experiments, physicochemical characterizations, possible expansion mechanisms, and catalytic properties. To be consistent with the literature and simplify the discussion, the IEZs are named as IEZ-ABC, M-IEZ-ABC, IEZ-Me-ABC, and M-IEZ-Me$A B C$, where " $A B C$ " is the code of the original zeolite structure, $M$ is the metal introduced into the zeolite by interlayer expansion, and $\mathrm{Me}$ is the metal from the original layered zeolite. The layered precursor zeolites and IEZs are listed in Table 2, along with the insertion agents. Furthermore, the ADOR (assembly-disassembly-organisation-reassembly) method is referenced as a special type of interlayer expansion. 
Table 2. Published synthesis routes involving IEZs of layered silicates.

\begin{tabular}{|c|c|c|c|c|c|}
\hline Layered Silicate & Zeolite Framework $^{1}$ & IEZ & Insertion Agent & Name in Refs. & Reference \\
\hline \multirow{3}{*}{ RUB-36 } & \multirow{7}{*}{$\mathrm{CDO}$} & IEZ-CDO & DEDMS, DCDMS & COE-4 & [52] \\
\hline & & M-IEZ-CDO ${ }^{2}$ & $\mathrm{FeCl}_{3}$ & M-COE-4 & {$[49,51]$} \\
\hline & & & Metal-acetylacetone & M-JHP-2 & \\
\hline Ti-RUB-36 & & IEZ-Ti-CDO & DHDMS & Ti-COE-4 & [50] \\
\hline \multirow{2}{*}{ Al-RUB-36 } & & IEZ-Al-CDO & DEDMS, DCDMS & Al-COE-4 & [53] \\
\hline & & Fe- IEZ-Al-CDO & $\mathrm{FeCl}_{3}$ & $\mathrm{Al}-\mathrm{COE}-4 / \mathrm{Fe}$ & [51] \\
\hline PLS-1 & & IEZ-CDS-1 & DCDMS & IEZ-2 & [47] \\
\hline $\mathrm{Nu}-6(1)$ & NSI & IEZ-NSI & DEDMS & IEZ-Nu-6 & [54] \\
\hline \multirow{2}{*}{ COK-5 } & \multirow{2}{*}{ MFS } & IEZ-MFS & DCDMS & COE-6 & [40] \\
\hline & & M-IEZ-MFS & Metal-acetylacetone $^{2}$ & $\mathrm{M}-\mathrm{COE}-6^{2}$ & [55] \\
\hline \multirow{2}{*}{$\begin{array}{l}\text { Me-MWW precursor }{ }^{3} \\
\text { Ti-MWW precursor }\end{array}$} & \multirow{2}{*}{ MWW } & IEZ-Me-MWW & DEDMS & IEZ-MWW & [38] \\
\hline & & IEZ-Ti-MWW & DEDMS & Ti-YNU-1 & [48] \\
\hline PREFER & \multirow[b]{2}{*}{ FER } & IEZ-FER & DEDMS & IEZ-FER & [56] \\
\hline PLS-3 & & Ti-IEZ-FER & $\mathrm{TiCl}_{4}$ & Ti-ECNU-8 & [57] \\
\hline
\end{tabular}

${ }^{1}$ The framework refers to the framework of calcined layered zeolites. ${ }^{2} \mathrm{M}=\mathrm{Fe}, \mathrm{Sn}, \mathrm{Zn}$, etc. ${ }^{3} \mathrm{Me}=\mathrm{Al}, \mathrm{Ga}, \mathrm{Fe}$, etc.

\section{Experiment}

\subsection{Synthesis of Layered Precursor Zeolites}

The zeolite precursor RUB-36 was synthesized from an initial gel with a composition of $1.0 \mathrm{SiO}_{2}: 0.5$ diethyl dimethyl ammonium hydroxide (DMDEAOH): $10 \mathrm{H}_{2} \mathrm{O}$ in an autoclave for 10-14 days at $140{ }^{\circ} \mathrm{C}$ [52]; The Me-RUB-36 was synthesized from a starting gel with $1.0 \mathrm{SiO}_{2}: 0.005-0.006 \mathrm{MeO}_{2}: 0.5 \mathrm{DMDEAOH}: 10-13 \mathrm{H}_{2} \mathrm{O}$ for 10 days at $140{ }^{\circ} \mathrm{C}[50,53]$; For the synthesis of the COK-5 zeolite, it is necessary to use $\mathrm{N}, \mathrm{N}, \mathrm{N}, \mathrm{N}^{\prime}, \mathrm{N}^{\prime}, \mathrm{N}^{\prime}$-hexamethyl pentane diammonium ( $\mathrm{Et}_{6}$-diquat-5) as an organic SDA. Then, $\mathrm{COK}-5$ is hydrothermally synthesized from a starting aluminosilicate gel with a composition of $1.0 \mathrm{SiO}_{2}: 0.015 \mathrm{Al}_{2} \mathrm{O}_{3}$ : $0.097 \mathrm{Na}_{2} \mathrm{O}: 0.105 \mathrm{SDA}: 41 \mathrm{H}_{2} \mathrm{O}$ at $160{ }^{\circ} \mathrm{C}$ for $132 \mathrm{~h}$ [58,59]; The Me-MWW precursor (where $\mathrm{Me}=\mathrm{Ti}, \mathrm{Al}, \mathrm{Ga}, \mathrm{Fe}$, etc.) was hydrothermally synthesized from the gel with a composition of $1.0 \mathrm{SiO}_{2}: 0.039 \mathrm{MeO}_{2}: 1.4 \mathrm{SDA}: 19 \mathrm{H}_{2} \mathrm{O}$ or $\mathrm{SiO}_{2}:(0-0.039) \mathrm{TiO}_{2}: 0.67 \mathrm{~B}_{2} \mathrm{O}_{3}: 1.4 \mathrm{SDA}: 19 \mathrm{H}_{2} \mathrm{O}$ at $140{ }^{\circ} \mathrm{C}$ for $7-10$ days under a rotation condition (100 rpm), where the organic SDA is hexamethyleneimine [60,61]; The FER lamellar precursor, so-called PREFER, was hydrothermally synthesized by using 4-amino-2,2,6,6-tetramethylpiperidine as an organic SDA. And the gel with the composition of $1.0 \mathrm{SiO}_{2}: 1.0 \mathrm{SDA}: 1.5 \mathrm{NH}_{4} \mathrm{~F}: 1.0 \mathrm{HF}: 15 \mathrm{H}_{2} \mathrm{O}$ is crystallized in an autoclave at $170{ }^{\circ} \mathrm{C}$ for seven days [29]; PLS-1 samples are converted from the mixture with a composition of $1.0 \mathrm{SiO}_{2}: 0.0989$ TMAOH:0.268 KOH:3.4 1,4-dioxane:14.5 $\mathrm{H}_{2} \mathrm{O}$ crystalized at $150^{\circ} \mathrm{C}$ for 10 days [47].

After crystallization, the solid product was filtered, washed, and dried at room temperature. The above as-synthesized precursors are calcined in air at $550{ }^{\circ} \mathrm{C}$ for $10 \mathrm{~h}$ to remove occluded organic SDA and thus form the corresponding zeolites with 3D structure.

\subsection{Synthesis of IEZ-ABC Zeolites}

The zeolite precursors are alkoxy silylated with interlayer-expansion agents in acidic medium. Typically, $1 \mathrm{~g}$ RUB-36, $0.13 \mathrm{~g}$ DCDMS, and $100 \mathrm{~mL} 0.1 \mathrm{M} \mathrm{HCl}$ are mixed and then transferred to an autoclave at $180{ }^{\circ} \mathrm{C}$ for $24 \mathrm{~h}$. The white powder obtained is named as IEZ-RUB-36. The samples obtained after calcination are named as IEZ-CDO (the calcined RUB-36 samples are CDO topology). Similarly, IEZ-Me-CDO samples are obtained by using the same procedure as IEZ-CDO but with IEZ-Me-CDO samples.

Metal cations could be introduced at the linker sites by applying the similar synthesis procedure in the following. Typically, M-IEZ-CDO ( $\mathrm{M}=\mathrm{Sn}, \mathrm{Fe}, \mathrm{Zn}$, etc.) is synthesized directly from RUB-36 in acidic conditions in the presence of the corresponding metal salt instead of silane reagents. For example, to get Fe-IEZ-CDO, $0.3 \mathrm{~g}$ of $\mathrm{FeCl}_{3} \cdot 6 \mathrm{H}_{2} \mathrm{O}, 0.7 \mathrm{~g}$ of 
RUB-36, and $12.5 \mathrm{~g}$ of $0.3 \mathrm{M} \mathrm{HCl}$, they undergo reaction in an autoclave for $24 \mathrm{~h}$ at $180{ }^{\circ} \mathrm{C}$. M-IEZ-Me-CDO samples are obtained by the same procedure as used for M-IEZ-CDO.

\section{Physicochemical Characterizations}

\subsection{Investigation of Interlayer Expansion with XRD and $\mathrm{N}_{2}$ Adsorption}

Interlayer-expansion agents with two methoxy groups are chosen to connect two adjacent layers, possibly by reacting with surface silanol groups. Various zeolitic lamellar precursors are interlayer-expanded with organic silanes in acidic media into highly ordered 3D crystalline zeolite materials. 2D lamellar precursors have special layered silicates considered as high silica hydrous layered silicates. The general structure of the layers consists of terminal $\mathrm{Si}-\mathrm{OH}$ or $\mathrm{Si}-\mathrm{O}$ groups sticking out into the inter-layer space. Organic SDA between the layers separates the silica layers. The calcination of lamellar precursors removes the organic SDA and thus condenses the high silica hydrous layered silicates [62]. The interlayer-expansion agents insert extra atoms between the neighboring layers, which increases the layer distance $[63,64]$. Therefore, the IEZs do not condense after calcination.

$X$-ray diffraction (XRD) reveals the layered crystal structures. Figure $1 \mathrm{a}-\mathrm{d}$ shows XRD patterns of RUB-36 and IEZ-RUB-36 before and after calcination [49,52]. The layerrelated diffraction of $\mathrm{CDO}$ (Figure $1 \mathrm{~b}$ ) shifts to higher $2 \theta$ compared with RUB-36 (Figure 1a), because RUB-36 is converted to the corresponding 3D crystalline structures after calcination. After treatment with DCDMS in acidic conditions, the IEZ-RUB-36 samples obtained showed a lower $2 \theta$ degree (from $8.14^{\circ}$ to $7.53^{\circ}$, see Figure 1c). The calcined sample IEZ$\mathrm{CDO}$ remains at a lower angle compared with $\mathrm{CDO}$, which means an increase in layer spacing. This phenomenon is due to the insertion between the layers of the silicon species from DCDMS. This species might react with the high silica hydrous layered silicates on the silicate layers and thereby connect neighboring layers, leading to turn the 8-MR of CDO into the 10-MR of IEZ-CDO. The Si-O-Si groups do not condense during calcination. Finally, the $d$ spacing increases from 9.2 to $11.7 \AA$, as shown in the Table 3 .

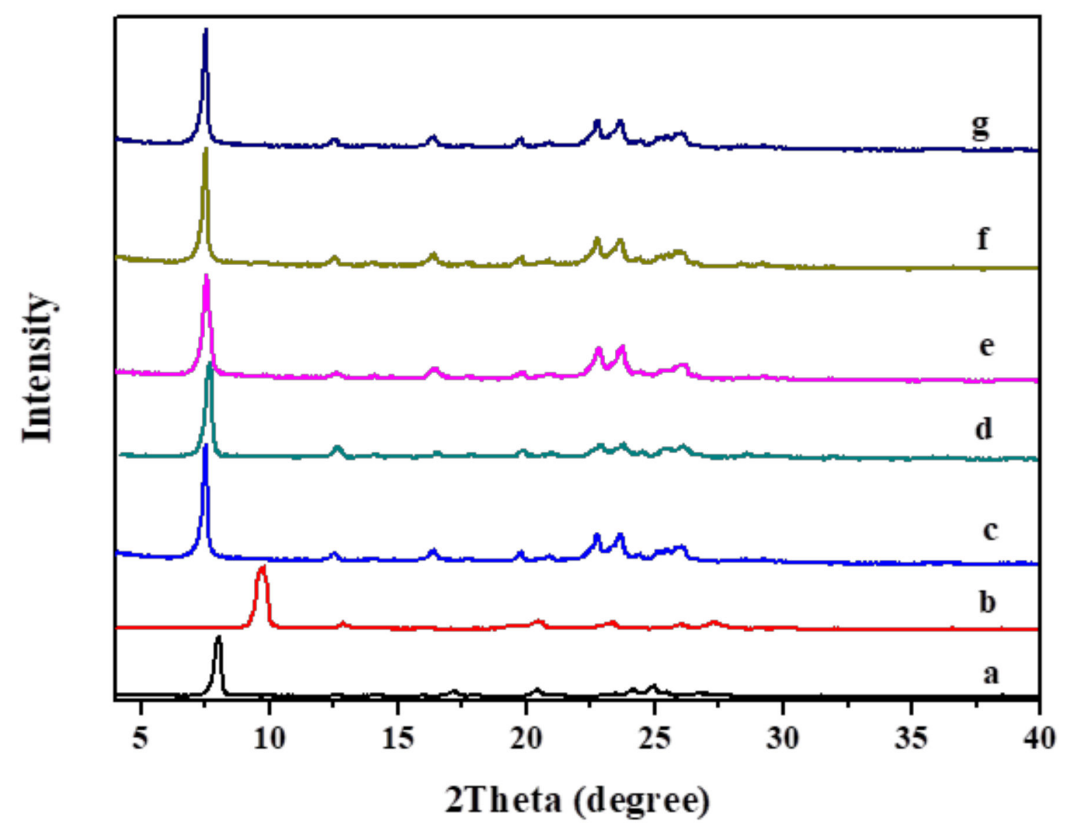

Figure 1. XRD patterns of (a) RUB-36, (b) CDO zeolite, (c) IEZ-RUB-36, (d) IEZ-CDO, (e) IEZ-AlRUB-36, (f) Fe-IEZ-RUB-36, and (g) Fe-IEZ-Al-RUB-36. Reprinted with permission from ref. [49]. Copyright 2020, MDPI. 
Table 3. Textural parameters of RUB-36 and the related zeolites.

\begin{tabular}{|c|c|c|c|c|c|c|}
\hline Name & $\begin{array}{c}\text { Chemical } \\
\text { Composition }\end{array}$ & $\begin{array}{c}\text { Surface Area } \\
\left(\mathrm{m}^{2} / \mathrm{g}\right)\end{array}$ & $\begin{array}{l}\text { Micro Volume } \\
\left(\mathrm{cm}^{3} / \mathrm{g}\right)\end{array}$ & $2 \theta$ degree $^{1}$ & $\begin{array}{c}d \text { Spacing }^{2} \\
\left(\AA^{2}\right)\end{array}$ & Reference \\
\hline RUB-36 & $\left(\mathrm{C}_{6} \mathrm{H}_{16} \mathrm{~N}\right)_{4}\left(\mathrm{H}_{4} \mathrm{Si}_{36} \mathrm{O}_{76}\right)$ & 40 & $<0.01$ & 8.14 & 11.2 & [52] \\
\hline CDO & $\mathrm{Si}_{36} \mathrm{O}_{72}$ & 288 & 0.12 & 9.76 & 9.2 & [52] \\
\hline IEZ-RUB-36 & $\mathrm{Si}_{20} \mathrm{O}_{38}\left(\mathrm{CH}_{3}\right)_{4}$ & 238 & 0.063 & 7.53 & - & [52] \\
\hline IEZ-CDO & $\mathrm{Si}_{20} \mathrm{O}_{38}(\mathrm{OH})_{4}$ & 350 & 0.131 & 7.92 & 11. 74 & [52] \\
\hline Fe-IEZ-CDO & $\mathrm{Si}_{19.14} \mathrm{Fe}_{0.86} \mathrm{O}_{38}(\mathrm{OH})_{4}$ & 423 & 0.156 & 7.90 & 11.7 & [51] \\
\hline Sn-IEZ-CDO & $\mathrm{Si}_{38.6} \mathrm{Sn}_{1.4} \mathrm{O}_{76}(\mathrm{OH})_{8}$ & 362 & 0.17 & 7.90 & 11.7 & [51] \\
\hline $\mathrm{Al}-\mathrm{CDO}$ & - & 231 & 0.09 & 8.14 & 9.2 & [65] \\
\hline IEZ-Al-CDO & - & 364 & 0.135 & 7.90 & 11.74 & [65] \\
\hline Fe-IEZ-Al-CDO & - & 389 & 0.136 & 7.89 & 11.7 & {$[65]$} \\
\hline Ti-CDO & - & 189 & 0.09 & 8.13 & - & {$[50]$} \\
\hline IEZ-Ti-CDO & - & 294 & 0.13 & 7.90 & - & [50] \\
\hline
\end{tabular}

${ }^{1}$ The $2 \theta$ degree refers to the layer-related diffraction, i.e., the $2 \theta$ degree of the first peak. ${ }^{2}$ The $d$-spacing data are derived from the first reflection in the powder XRD patterns.

Very interestingly, the incorporation of $\mathrm{Al}$ or Ti atoms into the $\mathrm{CDO}$ framework occurs in the original lamellar precursor synthesis. Al-RUB-36 or Ti-RUB-36 is incorporated into the RUB-36 framework via direct synthesis with addition of an $\mathrm{Al}$ or Ti source. And the interlayer expansion with DCDMS or DEDMS leads to the formation of IEZ-Al-RUB36 [53] (Figure 1e) or IEZ-Ti-RUB-36 [50]. Afterward, IEZ-Al-CDO or IEZ-Ti-CDO would be obtained after calcination. In addition, replacing silylated agents by $\mathrm{FeCl}_{3}, \mathrm{TiCl}_{3}$ or metal-acetylacetone during interlayer expansion of precursors results in M-IEZ-Me-ABC. For example, Fe-IEZ-RUB-36 and Fe-IEZ-Al-RUB-36 [51,65] (Figure 1f,g) are obtained by interlayer expansion of RUB-36 or Al-RUB-36 with $\mathrm{FeCl}_{3}$, respectively. The Fe-IEZ-CDO and Fe-IEZ-Al-CDO samples obtained after calcination show a similar shift with a $d$ spacing of $11.7 \AA$ (Table 2), indicating the similarity of the crystal framework obtained.

$\mathrm{N}_{2}$ adsorption is a powerful tool to characterize the surface area and microporous volume of the samples. Table 3 lists the parameters of CDO and related samples [49-53,65]. The original layer samples, RUB-36, have a small microporous volume. The microporous volume increases from $0.12 \mathrm{~m}^{3} / \mathrm{g}$ for CDO to $0.131 \mathrm{~m}^{3} / \mathrm{g}$ for IEZ-CDO after interlayer expansion (Table 2), which has also been confirmed by the result of XRD patterns. In addition, the surface area also increases due to the increased pore size. Of course, M-IEZCDO and IEZ-Me-CDO have similar change trends [51,65].

The same scenario occurs in the synthesis of IEZ-Me-MWW (Figure 2). The zeolite IEZTi-MWW is obtained by interlayer expansion of the precursor Ti-MWW $[36,48,66]$. Upon treatment in an acidic solution, the soluble silicon species from the zeolite crystals probably connect the $\mathrm{Si}-\mathrm{OH}$ between adjacent layers. The 10-MR in the Ti-MWW precursor converts into a 12-MR ring in IEZ-Ti-MWW, which increases transport rates and the potential to filter a larger product. PREFER with 8-MR turns into IEZ-FER with 10-MR upon silylation with DEDMS (Figure 2). The IEZs synthesis strategy also applies to a variety of lamellar precursors [67,68], such as IEZ-NSI from Nu-6(1) [54], IEZ-MFS from COK-5 [40], IEZ-FER from PREFER [56], and IEZ-CDS-1 from PLS-1 [47] (Table 2).

To obtain optimal conditions, $\mathrm{Wu}$ et al. studied the factors that affect interlayer expansion by silylation. Silylating the Nu-6(1) precursor with DEDMS produces IEZ-Nu6(1) [54]. Compared with the 3D NSI zeolite (curve b of Figure 3a), the calcined samples IEZ-NSI have a lower $2 \theta$, as seen in Figure 3. Although the (200) diffraction undergoes the same shift under different conditions, the strength of the peak indicates a different level of response. As seen in Figure 3a, the (200) diffraction is relatively broad and low in intensity when silylation is done in an aqueous solution. Interestingly, this condition is always acceptable for other precursors such as RUB-39 or RUB-36. As opposed to other precursors [69,70], increasing the volume of ethanol improves the order of IEZ-Nu-6(1). In addition, Figure $3 \mathrm{~b}$ shows that the higher temperatures are favorable for constructing 
well-ordered structures with interlayer-expanded pores. Furthermore, Figure $3 \mathrm{c}$ shows that the suitable acid concentration also leads to well-ordered structures. When $\mathrm{HCl}$ concentration is low $(0.5 \mathrm{M})$, it produces a mixture of $\mathrm{Nu}-6(1)$ precursor and IEZ-Nu-6(1); however, increasing the acid concentration above $2 \mathrm{M} \mathrm{HCl}$ partly dissolves the samples in the solution.

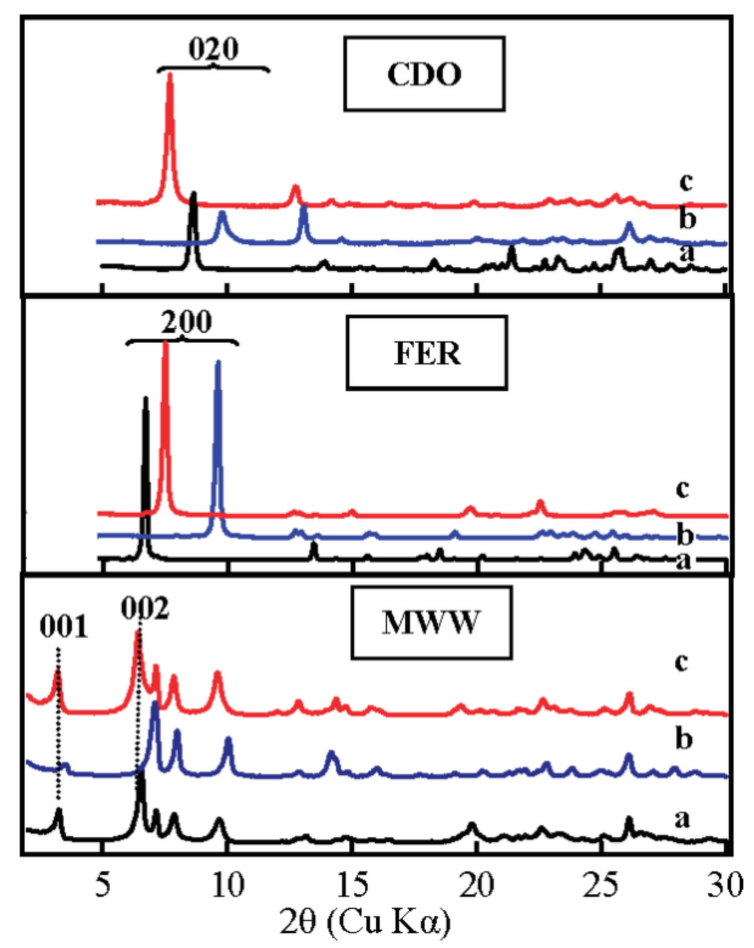

Figure 2. XRD patterns of (a) lamellar precursors, (b) 3D zeolites formed by the direct calcination of precursors, and (c) IEZs samples after further calcination. Reprinted with permission from ref. [36]. Copyright 2008, American Chemical Society.

Figure 3D shows how the amount of silane affects the structural order of IEZ-Nu-6(1). All of the (200) peaks undergo the same shift as a function of the amount of DEDMS (Figure 3D, curves b-e), which means that the similar interlayer expanded structure is obtained independent of the amount of silylated agent. The interlayer expanded structure is constructed even in the absence of DEDMS silane (Figure 3D, curve b) but it is of ow crystallinity. Similar phenomena have been reported for the direct acid treatment of postsynthesized Ti-MWW precursor [38,48]. Without interlayer expansion agents, soluble silicon species from the zeolite crystals probably serve as pillars to cross-link the layers.

In addition, it is worthy of note that, upon silylating the precursor COK-5 with DCDMS, the layer-related diffraction pattern shifts by a different degree (Figure 4) [40]. Samples with interlayers expanded with $x$ g DCDMS per g COK- 5 are denoted as IEZCOK-5- $x(x=0,0.185,0.375,0.830)$. When $x$ is less than 0.375 , the (001) peak shifts slightly to a lower angle. When $x$ is more than 0.375 , the peak remains at the same angle. This phenomenon might be caused by the layered structure with stacking disorder [59]. 
A)

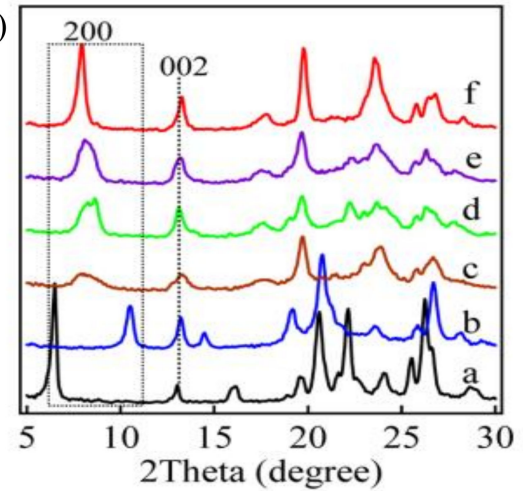

C)

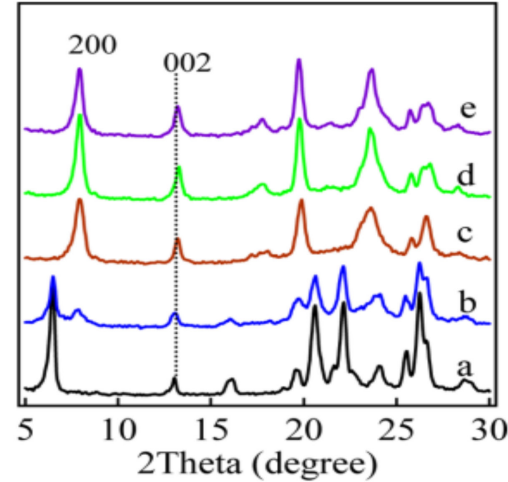

B)

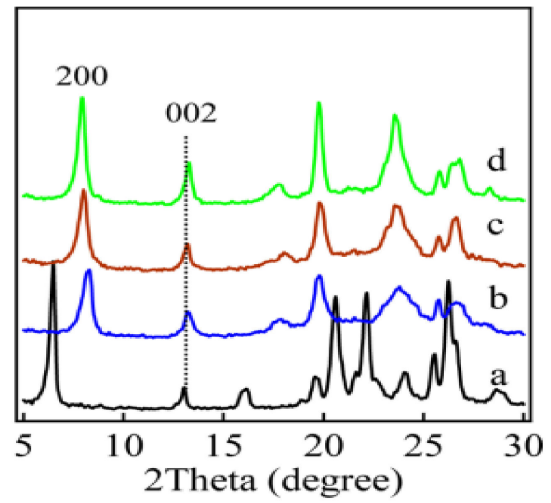

D)

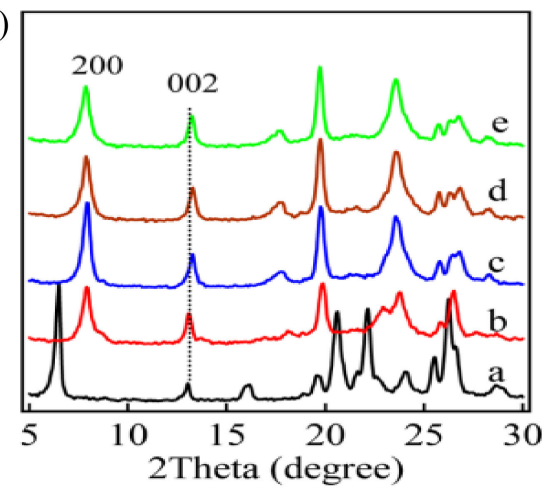

Figure 3. XRD patterns of (a) Nu-6(1) precursor (all silica), (A-b) NSI sample, and (from $\mathbf{A}-\mathbf{c}$ to $\mathbf{D}-\mathbf{e}$ ) IEZ-Nu-6(1) under different conditions. The main conditions consist of $0.5 \mathrm{~g}$ Nu-6(1), $0.08 \mathrm{~g}$ DEDMS, $473 \mathrm{~K}, 2 \mathrm{M} \mathrm{HCl}$ solution, for a duration of $24 \mathrm{~h}$. (A) XRD patterns for various solution compositions: (A-c) water, (A-d) ethanol $/ \mathrm{H}_{2} \mathrm{O}(1: 1),(\mathbf{A}-\mathbf{e})$ ethanol $/ \mathrm{H}_{2} \mathrm{O}(2: 1)$, (A-f) ethanol. (B) XRD patterns for various temperatures: (B-a) room temperature, (B-b) $403 \mathrm{~K}$, (B-c) $443 \mathrm{~K}$, (B-d) $473 \mathrm{~K}$. (C) XRD patterns for various acid concentrations: $(\mathbf{C}-\mathbf{b}) 0.5 \mathrm{M} \mathrm{HCl},(\mathbf{C}-\mathbf{c}) 1 \mathrm{M} \mathrm{HCl},(\mathbf{C}-\mathbf{d}) 2 \mathrm{M} \mathrm{HCl},(\mathbf{C}-\mathbf{e}) 3 \mathrm{M}$ $\mathrm{HCl}$. (D) XRD patterns for various amounts of DEDMS: (D-b) $0 \mathrm{~g}$, (D-c) $0.08 \mathrm{~g}$, (D-d) $0.13 \mathrm{~g}$, and (D-e) 0.18 g. Reprinted with permission from ref. [54]. Copyright 2013, American Chemical Society.

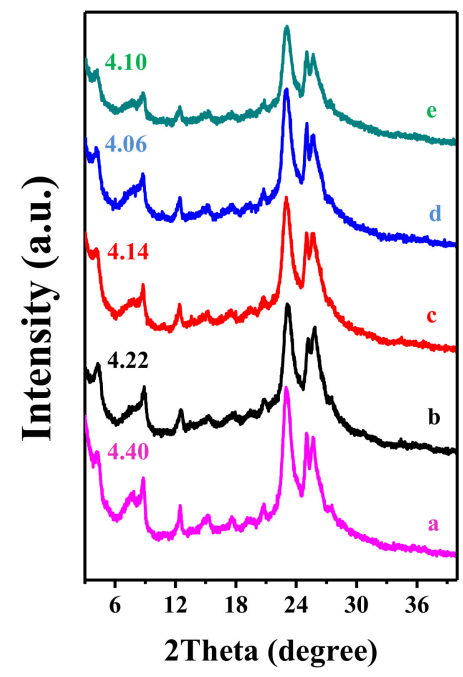

Figure 4. XRD patterns of (a) as-synthesized COK-5, (b) IEZ-COK-5-0, (c) IEZ-COK-0.185, (d) IEZCOK-0.375, and (e) IEZ-COK-0.830. Reprinted with permission from ref. [40]. Copyright 2015, Elsevier.

\subsection{Investigation of Interlayer Expansion with Electron Microscopy}

The scanning electron microscopy (SEM) technique is usually used for revealing the crystal morphology. However, despite the IEZ reactions varying the separation between 
adjacent layers, the layer precursors and related IEZ materials retain a very similar morphology. Figure 5a-d show the SEM images of (a) RUB-36, (b) IEZ-CDO, (c) Fe-IEZ-CDO, and (d) Fe-IEZ-Al-CDO. All images exhibit a similar morphology with nanosheets. These results indicate that the interlayer expansion does not influence the sample morphology, which are similar with other references reported [36].
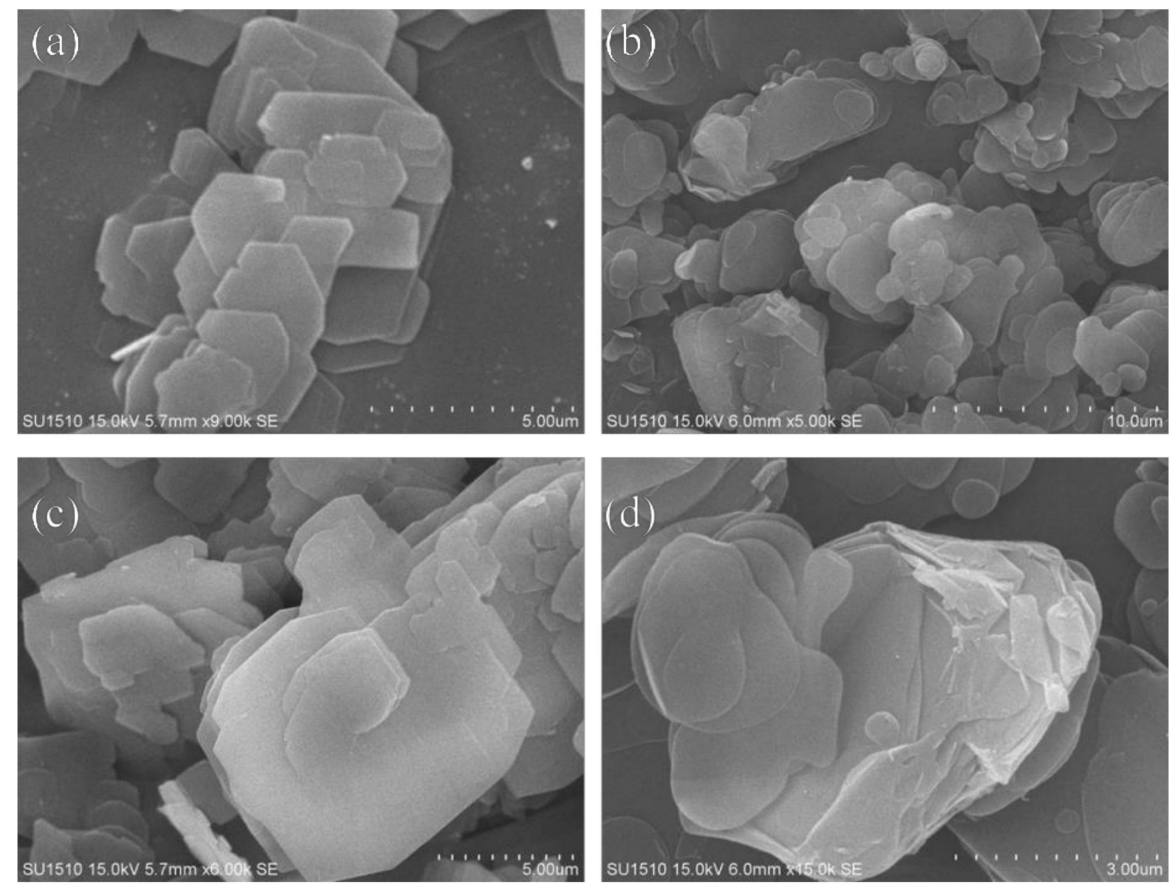

Figure 5. SEM images of (a) RUB-36, (b) IEZ-CDO, (c) Fe-IEZ-CDO and (d) Fe-IEZ-Al-CDO. Reprinted with permission from ref. [49]. Copyright 2020, MDPI.

High-resolution transmission electron microscopy (HR-TEM) could reveal the spacing between neighboring layers, which can provide direct evidence of the interlayer expansion. Figure 6A shows HRTEM images taken of the edge of the COK-5 and IEZ-COK-5 crystallites [40]. Three layers in IEZ-COK-5 spans are $3.161 \mathrm{~nm}$ (see inset in Figure 6A/b), which slightly exceeds the $3.005 \mathrm{~nm}$ spanned by three layers in COK-5 (see inset in Figure 6A/a), confirming that the interlayer expansion occurs along the $c$ axis upon treating COK-5 with DCDMS. The same phenomenon could be observed in the interlayer expansion of Ti-MWW [38] (Figure 6B). The distance spanned by 10 layers in IEZ-Ti-MWW (Figure 6B/b) is comparable to that spanned by 11 layers in 3D Ti-MWW (Figure 6B/a), which reveals the expansion between neighboring layers in the former.

Figure 7A compares selected-area electron diffraction of 3D MWW and IEZ-Ti-MWW along two directions (100) and (001), and Table 4 lists the $d$ spacings given by HRTEM between 3D MWW and IEZ-Ti-MWW [36]. The results show that IEZ-Ti-MWW has a pore array and pore size, which are remarkably similar with that of the 3D structure obtained by direct calcination in the layer. However, the well-ordered pores expand along the (001) direction from 25.3 to $28.2 \AA$. And this pore expansion is consistent with the XRD evidence that the pores enlarge from 10 to 12-MR. As shown in Figure 7B, the $d$ spacing along the (200) direction also increases from $9.8 \AA$ for 3D-FER to $12.1 \AA$ for IEZ-FER. 
A)

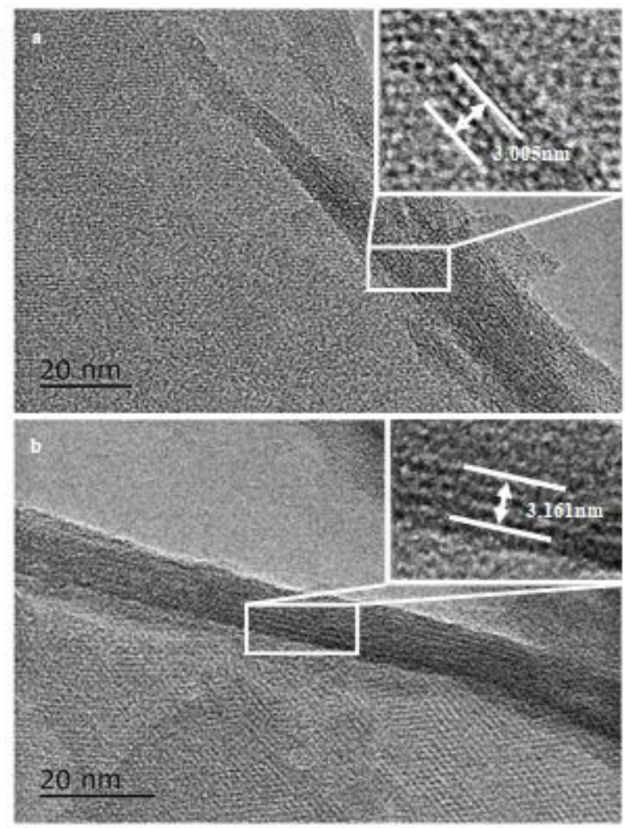

B)

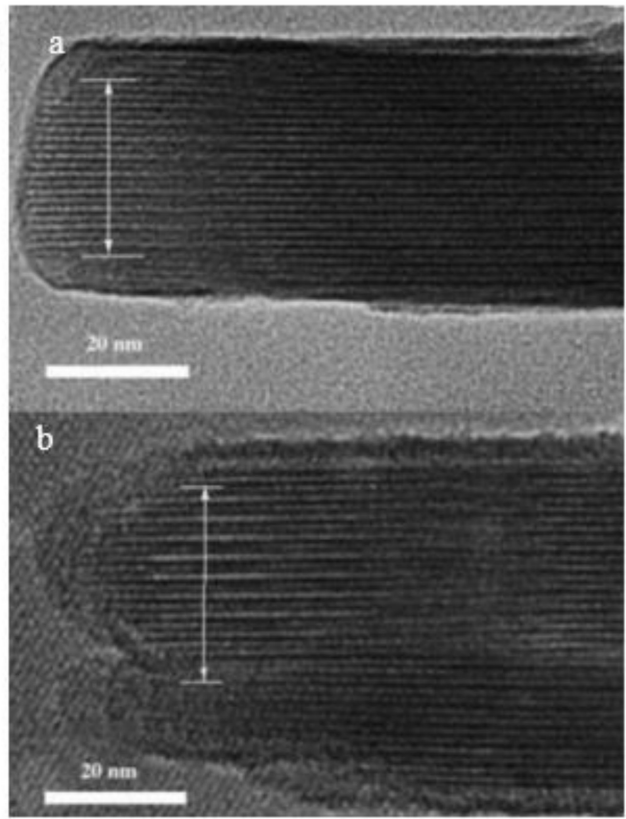

Figure 6. HRTEM images of (A)/(a) COK-5, (A)/(b) IEZ-MFS, (B)/(a) Ti-MWW, and (B)/(b) IEZ-Ti-MWW. Reprinted with permission from ref. [38,40]. Copyright 2004, Wiley and Copyright 2015, Elsevier.

A)
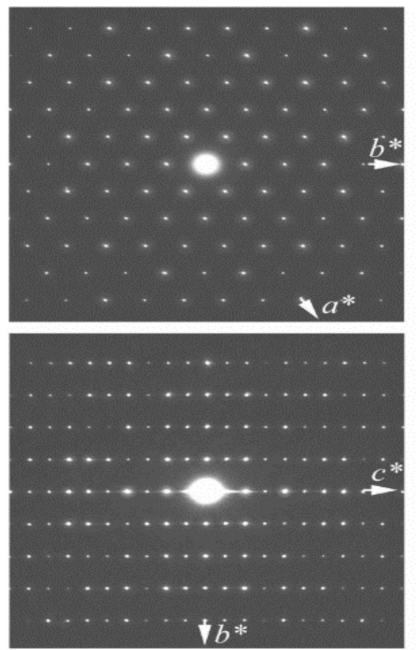
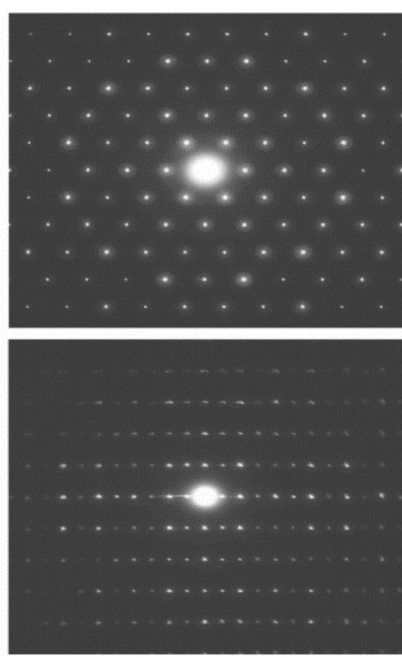

B)
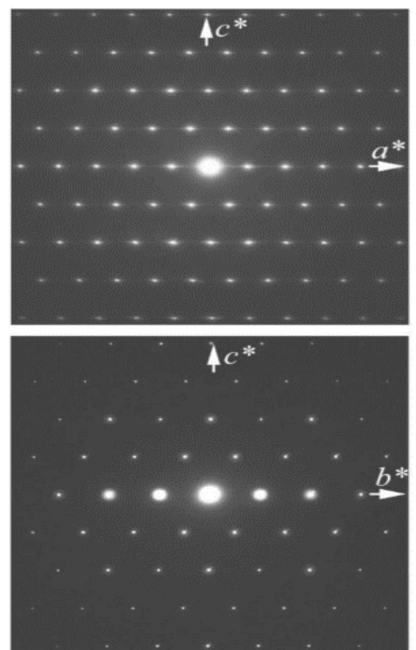
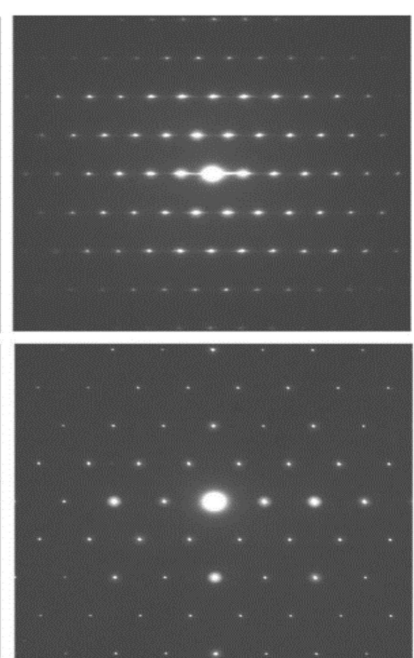

Figure 7. Selected-area electron diffraction patterns of (A) 3D MWW (left), IEZ-Ti-MWW (right) and (B) 3D-FER (left), IEZ-FER (right). Reprinted with permission from ref. [36]. Copyright 2008, American Chemical Society.

Table 4. $d$ spacing determined by HRTEM for 3D zeolites after calcination and IEZ samples. Reprinted with permission from ref. [36]. Copyright 2008, American Chemical Society.

\begin{tabular}{cccc}
\hline \multirow{2}{*}{ Structure Type } & \multicolumn{3}{c}{$\boldsymbol{d}$ Spacing $(\AA)$} \\
\cline { 2 - 4 } & $\boldsymbol{h} \boldsymbol{k l}$ & 3D Zeolites & IEZ Samples \\
\hline \multirow{2}{*}{ MWW } & 100 & 12.3 & 12.7 \\
& 001 & 25.3 & 28.2 \\
\hline \multirow{2}{*}{ FER } & 200 & 9.8 & 12.1 \\
& 020 & 7.3 & 7.2 \\
\hline
\end{tabular}




\subsection{Investigation of Interlayer Expansion by Infrared Spectroscopy and Contact Angle}

Infrared (IR) spectroscopy is always used to monitor the silylation of the lamellar precursors. With the as-synthesized lamellar precursors, an IR absorption peak appears in IEZ samples at $850 \mathrm{~cm}^{-1}$, which is assigned to asymmetric stretching of $-\mathrm{CH}_{3}$ groups attached to Si species [71-73], confirming the incorporation of the $\left(\mathrm{CH}_{3}\right)_{2} \mathrm{Si}$ moiety into the zeolite. To investigate how the amount of silane affects the structural order, we study in detail the interlayer expansion of COK-5 with different amounts of silane as interlayer expansion agents. The intensity of the $850 \mathrm{~cm}^{-1}$ band increases with the increasing DCDMS amount, and then levels off at a silane-to-precursor weight ratio of $0.375 \mathrm{~g} / \mathrm{g}$ (Figure 8), indicating that no further silane groups can be incorporated. The intensity of the $850 \mathrm{~cm}^{-1}$ band even decreases when the silane-to-precursor weight ratio exceeds $0.375 \mathrm{~g} / \mathrm{g}$, which is attributed to excessive silylation, reducing the $\mathrm{pH}$ of the solution and thereby hindering the further incorporation of $\mathrm{Si}\left(\mathrm{CH}_{3}\right)_{2}$ moiety. The above results are consistent with the XRD results.

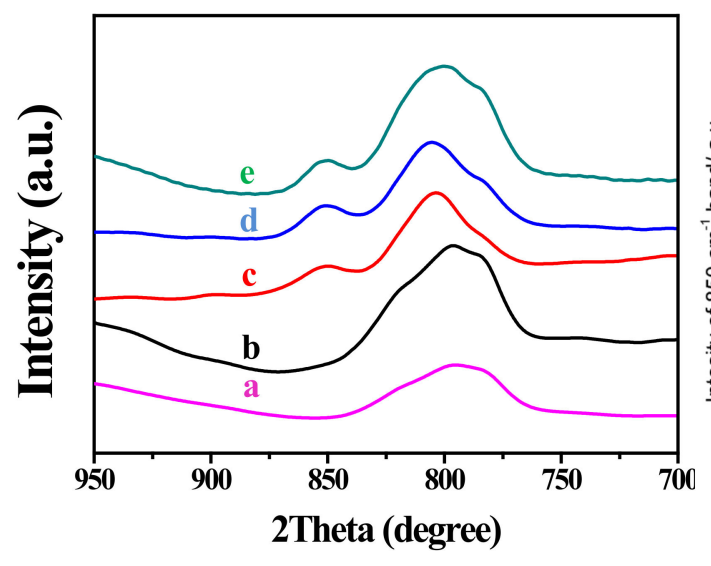

(A)

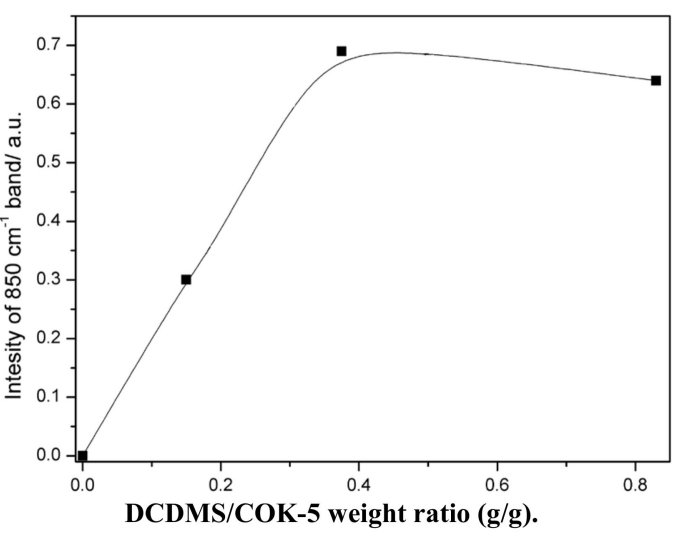

(B)

Figure 8. (A) IR spectra of (a) COK-5, (b) IEZ-COK-5-0, (c) IEZ-COK-5-0.185, (d) IEZ-COK-5-0.375, (e) IEZ-COK-5-0.830. (B) Intensity of $850 \mathrm{~cm}^{-1}$ band as a function of the amount of DCDMS used in the silylation of COK-5. Reprinted with permission from ref. [40]. Copyright 2015, Elsevier.

As known, most lamellar precursors currently studied are silicate crystals, and interesting phenomena occur in the aluminosilicate zeolite COK-5. When it is treated in an acidic solution, $\mathrm{Al}$ atoms from the aluminosilicate zeolite dissolve in the solution, and the increased $\mathrm{Si} / \mathrm{Al}$ ratio decreases the wettability. Meanwhile, the interlayer expansion caused by the silylated agent introduces $\mathrm{Si}-\left(\mathrm{CH}_{3}\right)_{2}$ groups into the lamellar precursor, increasing the hydrophobicity. Table 5 and Figure 9 show the contact angles of water on the surface of COK-5, MFS, IEZ-COK-5, and IEZ-MFS produced with varying amounts of DCDMS [40]. The contact angle of COK-5 is about $22^{\circ}$, whereas calcined COK-5 (called MFS) produces a contact angle of $27^{\circ}$. This phenomenon might be related to the fact that calcination causes hydrophilic hydroxyl groups to condensate between layer and layer. When COK-5 zeolites are immersed in $\mathrm{HCl}$ solution without any DCDMS, the IEZ-COK-5-0 obtained produces a greater contact angle of $56^{\circ}$, which is attributed to the loss of $\mathrm{Al}$ atoms $(\mathrm{Si} / \mathrm{Al}=74)$, as confirmed by the $\mathrm{Si} / \mathrm{Al}$ ratio. Moreover, calcined IEZ-COK-5-0 (called IEZ-MFS-0) produces a small contact angle of $27^{\circ}$, which is the same as the contact angle of MFS. This phenomenon is tentatively attributed to the loss of $\mathrm{Al}$ atoms, which has the same effect as the condensation of hydrophilic hydroxyl groups. Besides, the high $\mathrm{Al}$ content (the $\mathrm{Si} / \mathrm{Al}$ ratio is as low as 11-12) can strongly impact the silylation for the leaching of framework $\mathrm{Al}$ species during interlayer expansion in a strongly acidic condition. The IEZ-Al-MWW could be obtained when the $\mathrm{Si} / \mathrm{Al}$ ratio of Al-MWW is higher than $30[36,74,75]$. 

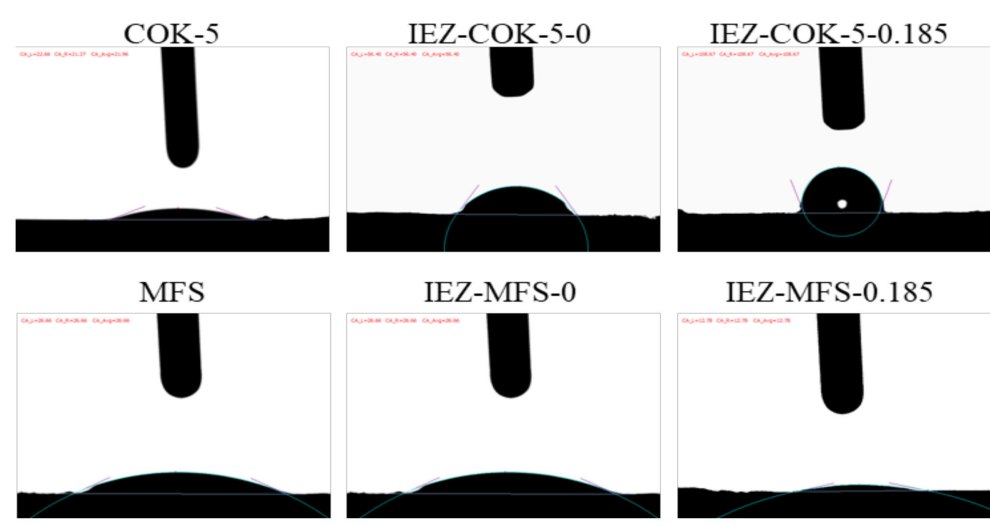

IEZ-MFS-0

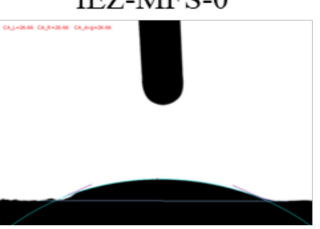

IEZ-MFS-0.185

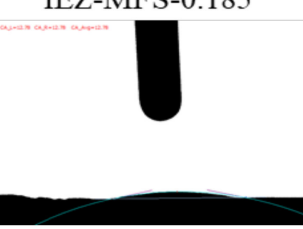

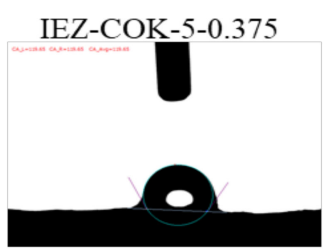

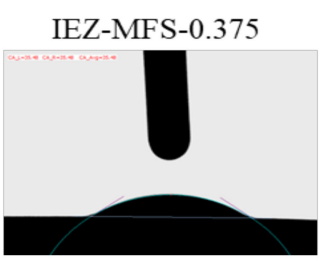

IEZ-COK-5-0.830

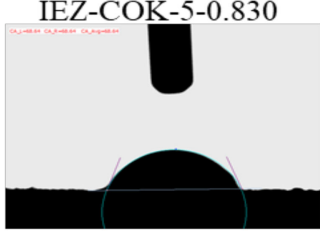

IEZ-MFS-0.875

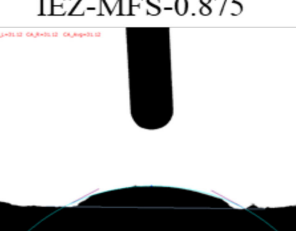

Figure 9. Contact angles of water on surface of COK-5, MFS, IEZ-COK-5, and IEZ-MFS produced using different amounts of DCDMS. Reprinted with permission from ref. [40]. Copyright 2015, Elsevier.

Table 5. Physicochemical properties of MFS and IEZ-MFS under different conditions. Reprinted with permission from ref. [40]. Copyright 2015, Elsevier.

\begin{tabular}{|c|c|c|c|c|}
\hline Zeolite & $\begin{array}{c}\text { DCMDS }^{1} \\
\text { (g/g of COK-5) }\end{array}$ & Si/Al Ratio ${ }^{2}$ & Contact Angle 3 & $\begin{array}{c}\text { Contact Angle } \\
\text { before Calcination }\end{array}$ \\
\hline MFS & - & 24 & $27^{\circ}$ & $28^{\circ}$ \\
\hline IEZ-MFS-0 & 0 & 74 & $27^{\circ}$ & $56^{\circ}$ \\
\hline IEZ-MFS-0.185 & 0.185 & 40 & $13^{\circ}$ & $109^{\circ}$ \\
\hline IEZ-MFS-0.375 & 0.375 & 36 & $41^{\circ}$ & $120^{\circ}$ \\
\hline IEZ-MFS-0.830 & 0.830 & 40 & $31^{\circ}$ & $69^{\circ}$ \\
\hline
\end{tabular}

${ }^{1}$ Samples were treated with DCDMS in $1 \mathrm{M} \mathrm{HCl}$ at $180^{\circ} \mathrm{C}$ for $24 \mathrm{~h} .{ }^{2} \mathrm{Si} / \mathrm{Al}$ ratios were measured by ICP technique. ${ }^{3}$ The contact angles were measured for water on the surface. ${ }^{4}$ The contact angles before calcination refers to the contact angles of COK-5, IEZ-COK-5-0, IEZ-COK-5-0.185, IEZ-COK-5-0.375, IEZ-COK-5-0.830.

Upon treating COK-5 with DCDMS, the IEZ-COK-5 produced has an increased contact angle, which is attributed to the increased concentration of methyl groups in the zeolite framework [76-78]. The contact angle decreased when more than $0.375 \mathrm{~g}$ of DCDMS was added per gram of COK- 5 because the extra DCDMS turns into $\mathrm{HCl}$, which destroys aluminosilicate crystals. After calcination at $550{ }^{\circ} \mathrm{C}$ for $4 \mathrm{~h}$, the contact angle of IEZMFS decreases, which is interpreted as a change in wettability due to methyl groups generated by calcination of hydrophilic silanols [77]. The contact angle of IEZ-MFS-0.185 goes to minimal value because the $\mathrm{Si} / \mathrm{Al}$ ratio remains at 40 , and the interlayer expansion incorporates the $\mathrm{Si}-\mathrm{OH}$ groups into the zeolite framework. This phenomenon demonstrates the hydrophobic nature of the as-made IEZ materials. Clearly, the sample wettability may be tuned by inserting methyl groups and transforming methyl to silanol. Therefore, the contact angle of water can be tuned by adjusting the dosage of DCMDS.

\subsection{Investigation of Interlayer Expansion by ${ }^{13} \mathrm{C}$ and ${ }^{29} \mathrm{Si} N \mathrm{NR}$ Spectroscopy}

The incorporation of $\left(\mathrm{CH}_{3}\right)_{2} \mathrm{Si}$ groups by the silylation of lamellar precursors is further investigated by ${ }^{13} \mathrm{C}$ magic-angle spinning (MAS) NMR and ${ }^{29} \mathrm{Si}$ MAS NMR techniques. Most silylation agents include $\mathrm{Si}\left(\mathrm{CH}_{3}\right)_{2}$ groups, which connect to $\mathrm{Si}-\mathrm{OH}$ between adjacent layers. In contrast with the original lamellar precursor, the IEZ samples without further calcination retain the $\mathrm{Si}\left(\mathrm{CH}_{3}\right)_{2}$ groups. Using COK-5 and IEZ-COK-5 as an example, silylation produces a new resonance with the chemical shift at $-2.0 \mathrm{ppm}$ in the ${ }^{13} \mathrm{C}$ MAS NMR spectrum (Figure 10A-b), which is due to the configuration of the $\mathrm{Si}\left(\mathrm{CH}_{3}\right)_{2}$ groups [73,79]. This result also confirmed by the IR spectra result. In addition, COK-5 produces two strong peaks with the chemical shift at -113 and $-101 \mathrm{ppm}$ in the spectra of ${ }^{29} \mathrm{Si}$ MAS NMR, which are associated with the $\mathrm{Si}(\mathrm{SiO})_{4}\left(\mathrm{Q}^{4}\right)$ and $(\mathrm{OH}) \mathrm{Si}(\mathrm{SiO})_{3}\left(\mathrm{Q}^{3}\right)$ species, respectively. Furthermore, IEZ-COK-5 produces an additional peak with the chemical shift at $-17 \mathrm{ppm}$ in the spectra of ${ }^{29} \mathrm{Si}$ MAS NMR, which is attributed to the $\mathrm{Si}\left(\mathrm{CH}_{3}\right)_{2}(\mathrm{SiO})_{2}\left(\mathrm{D}^{2}\right)$ species. The 
peaks with the chemical shift at -53 and $-67 \mathrm{ppm}$ are assigned to the $\mathrm{Si}\left(\mathrm{CH}_{3}\right)(\mathrm{OH})(\mathrm{SiO})_{2}$ $\left(\mathrm{T}^{2}\right)$ and $\mathrm{Si}\left(\mathrm{CH}_{3}\right)(\mathrm{SiO})_{3}\left(\mathrm{~T}^{3}\right)$ species. These results show that the $\mathrm{Si}\left(\mathrm{CH}_{3}\right)_{2}$ species is indeed inserted into the zeolite framework [80-82]. Notice in particular that, compared with COK-5, IEZ-COK-5 has a low concentration of the $Q^{3}$ species, indicating that silylation occurs through the reaction of silane groups with the silanols on the layer surface to link neighboring layers to a microporous framework silicate with functionalized bridging linker groups [-O-Si $\left.\left(\mathrm{CH}_{3}\right)_{2}-\mathrm{O}-\right]$ [82].

A)

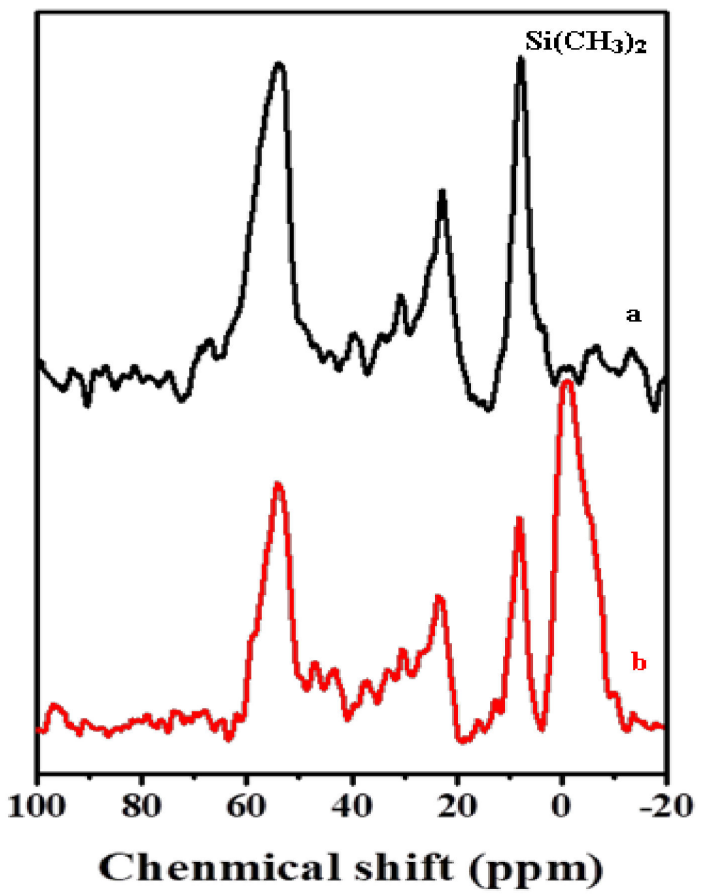

B)

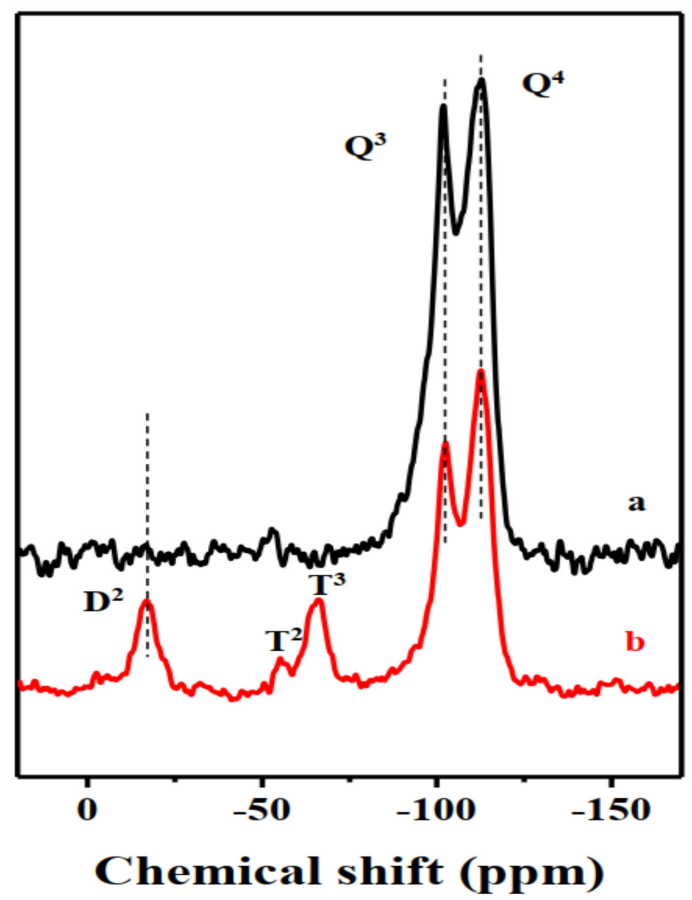

Figure 10. (A) ${ }^{13} \mathrm{C}$ MAS NMR spectra and (B) ${ }^{29}$ Si MAS NMR spectra of (a) COK-5 and (b) IEZ-COK-5. Reprinted with permission from ref. [40]. Copyright 2015, Elsevier.

The use of a metal salt instead of a silylating agent to drive an interlayer expansion of a lamellar precursor causes the same shift in the first reflection. As shown in Figures 3D and 11, acid treatment separates adjacent layers, allowing soluble silicon species from zeolite crystals to construct the interlayer-expanded structure. To confirm the coordination state of the incorporated iron species, single pulse (Figure 11, top) and $\mathrm{H}-\mathrm{CP}{ }^{29} \mathrm{Si}$ MAS NMR techniques (Figure 11, bottom) are used to analyze (A) acid-only-treated RUB-36, (B) Fe-IEZ-CDO, and (C) IEZ-Al-CDO (see Figure 11A-C) $[65,83,84]$. For H-CP ${ }^{29} \mathrm{Si}$ MAS, in particular, the peaks with the chemical shift around $-112 \mathrm{ppm}$ are attributed to the $\mathrm{Q}^{3}$ species $\left[\mathrm{Si}(\mathrm{OSi})_{3} \mathrm{Fe}\right.$ or $\left.\mathrm{Si}(\mathrm{OSi})_{3} \mathrm{OH}\right]$. In the series formed by acid-only-treated RUB-36, IEZ-Al-CDO, and Fe-IEZ-CDO, the iron species content increases, whereas the signal with the chemical shift at $-91 \mathrm{ppm}\left[\mathrm{Q}^{2}, \mathrm{Si}(\mathrm{OSi})_{3}(\mathrm{OH})_{2}\right]$ decreases. This result suggests that, in the presence of iron species, the linking sites are occupied by $-\mathrm{Fe}(\mathrm{OH})_{2}$ - instead of by $\mathrm{Si}(\mathrm{OH})_{2}$ groups alone. 

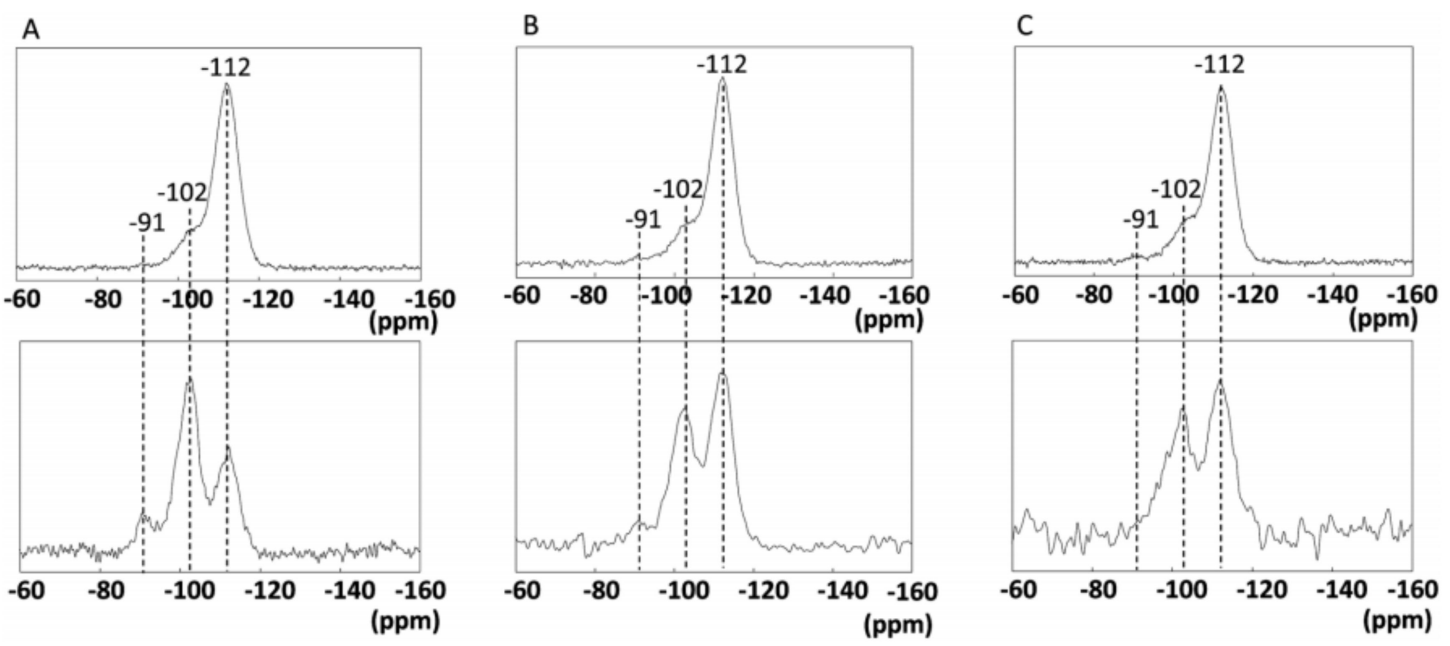

Figure 11. Single pulse (top) and $\mathrm{H}-\mathrm{CP}{ }^{29}$ Si MAS NMR spectra (bottom) of (A) acid-only-treated RUB-36, (B) Fe-IEZ-CDO, and (C) IEZ-Al-CDO. Reprinted with permission from ref. [65]. Copyright 2014, The Royal Society of Chemistry.

\subsection{Investigation of Interlayer Expansion with UV-vis and X-ray Photoelectron Spectroscopy}

UV-vis absorption spectroscopy has been used to confirm that the metal atom is indeed incorporated at isolated sites. The original precursors produce no clear peaks because no metal is present [49]. However, once metal species are incorporated, the UV-vis spectra reflect the environment of these metal species $[49,65]$. Figure 12 compares the UV-vis spectra of Fe-IEZ-CDO, Fe-IEZ-Al-CDO, and normal $\mathrm{Fe}_{2} \mathrm{O}_{3}-\mathrm{ZSM}-5$. Both Fe-IEZ-CDO and Fe-IEZ-Al-CDO contain one major absorption peak, representing the isomorphous substitution of Fe species in the framework $[85,86]$. On the contrary, normal $\mathrm{Fe}_{2} \mathrm{O}_{3}-\mathrm{ZSM}-5$ produces a broad adsorption spectrum around $400 \mathrm{~nm}$ [87-89], indicating that Fe species in Fe-IEZ-CDO and Fe-IEZ-Al-CDO should be isolated.

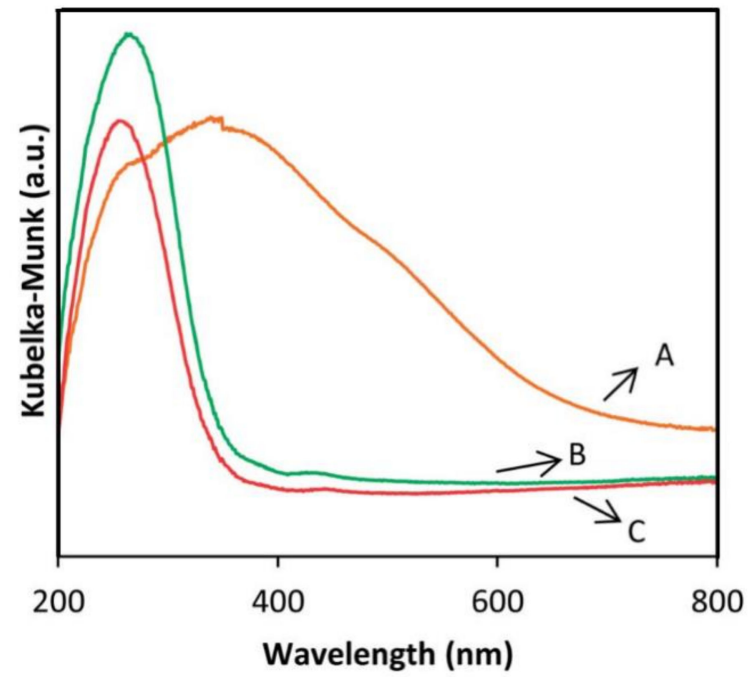

Figure 12. UV-vis spectra of (A) $\mathrm{Fe}_{2} \mathrm{O}_{3}-\mathrm{ZSM}-5$, (B) Fe-IEZ-CDO, and (C) Fe-IEZ-Al-CDO. Reprinted with permission from ref. [65]. Copyright 2014, The Royal Society of Chemistry.

X-ray photoelectron spectroscopy (XPS) is an important surface analysis technique. It not only provides information on molecular structure and the atomic valence state for chemical research, but also provides information on elemental composition, chemical state, and molecular structure. Figure 13 shows $S n 3 d_{5 / 2}$ and $3 d_{3 / 2}$ spectra for Sn-IEZ-COK-5 and Sn-IEZ-MFS, giving binding energies of 487.3 and $495.6 \mathrm{eV}$, respectively, which exceeds that of $\mathrm{SnO}_{2}$ crystals (485.8 and $494.4 \mathrm{eV}$, respectively). This phenomenon can be monitored by the isolated tin species in the zeolite framework [90-93]. 


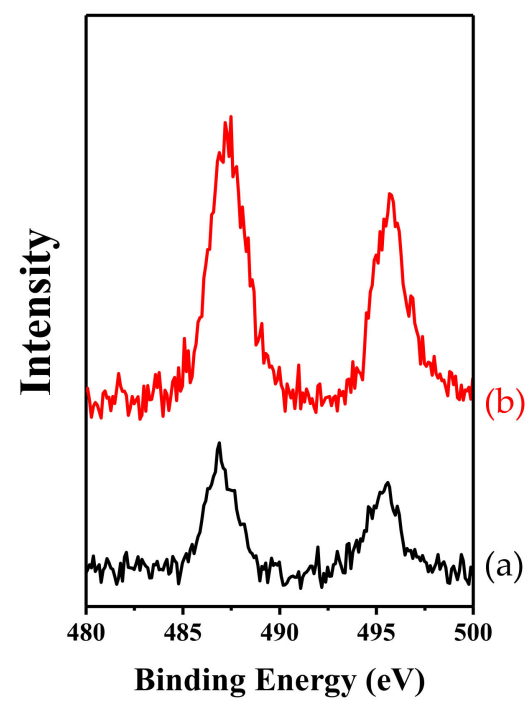

Figure 13. Sn $3 d_{5 / 2}$ and $3 d_{3 / 2}$ spectra of (a) Sn-IEZ-COK-5 and (b) Sn-IEZ-MFS. Reprinted with permission from ref. [55]. Copyright 2015, Elsevier.

\section{Possible Mechanism}

The above results allow us to propose a mechanism for constructing new zeolite structures by interlayer expansion of a layered precursor. A typical example is the formation of IEZ-PLS-1 and IEZ-CDS-1 from PLS-1, as shown in Figure 14 [47], The layered silicate PLS-1 has the chemical formula $\left.\mathrm{K}_{1.3}\left[\left(\mathrm{CH}_{3}\right)_{4} \mathrm{NOH}\right]_{1.7} \mathrm{Si}_{18} \mathrm{O}_{40}(\mathrm{OH})_{4}\right]$ Generally, 3D CDS-1 zeolites can be obtained by calcinating the PLS-1 lamellar precursor while condensing hydroxyl groups between adjacent layers. CDS- $1\left(\mathrm{Si}_{36} \mathrm{O}_{72}, \mathrm{CDO}\right)$ consists of two 8-MR along the (001) and (010) directions. After silylation with DCDMS, 3D crystals of IEZ-PLS-1 are obtained with $\mathrm{Si}\left(\mathrm{CH}_{3}\right)_{2}$ groups incorporated. After calcination at $500{ }^{\circ} \mathrm{C}$ in air, the methyl groups attach to the interlayer silicon atoms and turn into hydroxyl groups. The sample obtained is denoted as IEZ-CDS-1. The interlayer silylation of CDS-1 increases from 8 to $10 \mathrm{MR}$ along (020) direction.

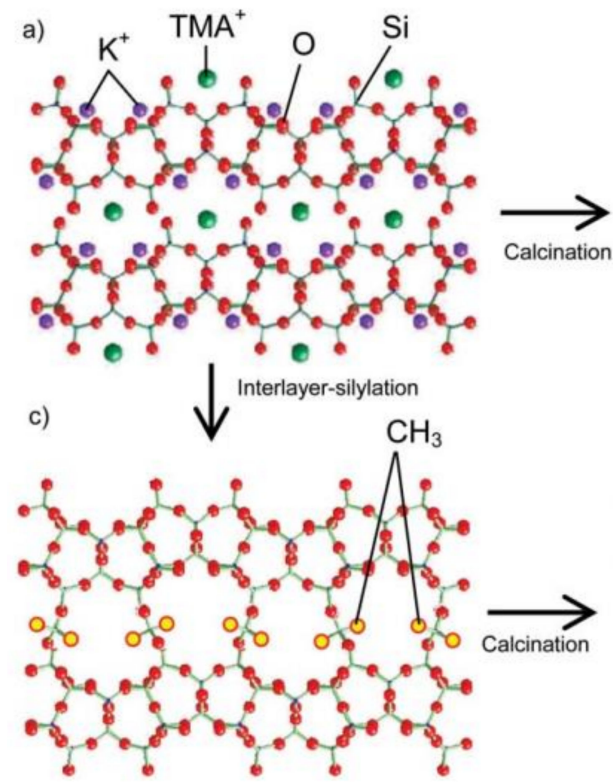

b)

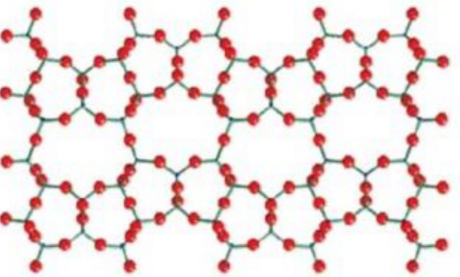

d)

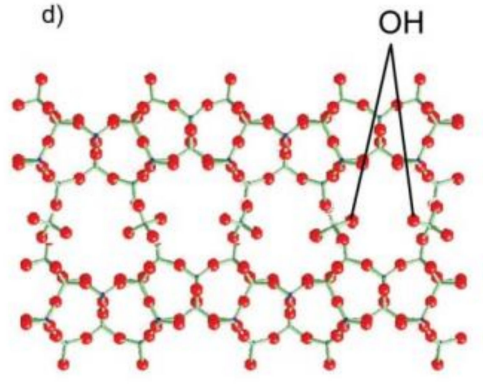

Figure 14. Possible schemes for the formation of the interlayer-expanded structure by the intercalation of DCDMS molecules: (a) PLS-1, (b) CDS-1, (c) IEZ-PLS-1, and (d) IEZ-CDS-1. Reprinted with permission from ref. [47]. Copyright 2007, Royal Society of Chemistry. 
The introduction of metal atoms at the linker sites with metal salts is reminiscent of similar formation mechanisms as the silylation progresses $[65,94]$. Taking Fe-IEZ-CDO as an example, the $\mathrm{FeCl}_{3}$ agents insert irons species connecting the silicon species of adjacent layers to form Fe-IEZ-RUB-36. After calcination, the irons species convert into - $\mathrm{O}-\mathrm{Fe}(\mathrm{OH})_{2}-$ $\mathrm{O}$ - groups and the samples convert into Fe-IEZ-CDO. Figure 15 shows clearly the detail in Fe-IEZ-CDO samples, with the link across the interlayer space clearly shown [51]. As opposed to the CDO structure, the linker -O-Fe(OH) $)_{2}-\mathrm{O}$ - groups attach to the interlay silicon atoms. The interlayer expansion thus increases of the layer distance, which increases the microporous volume and allows extra-atoms to insert themselves at the linker sites.

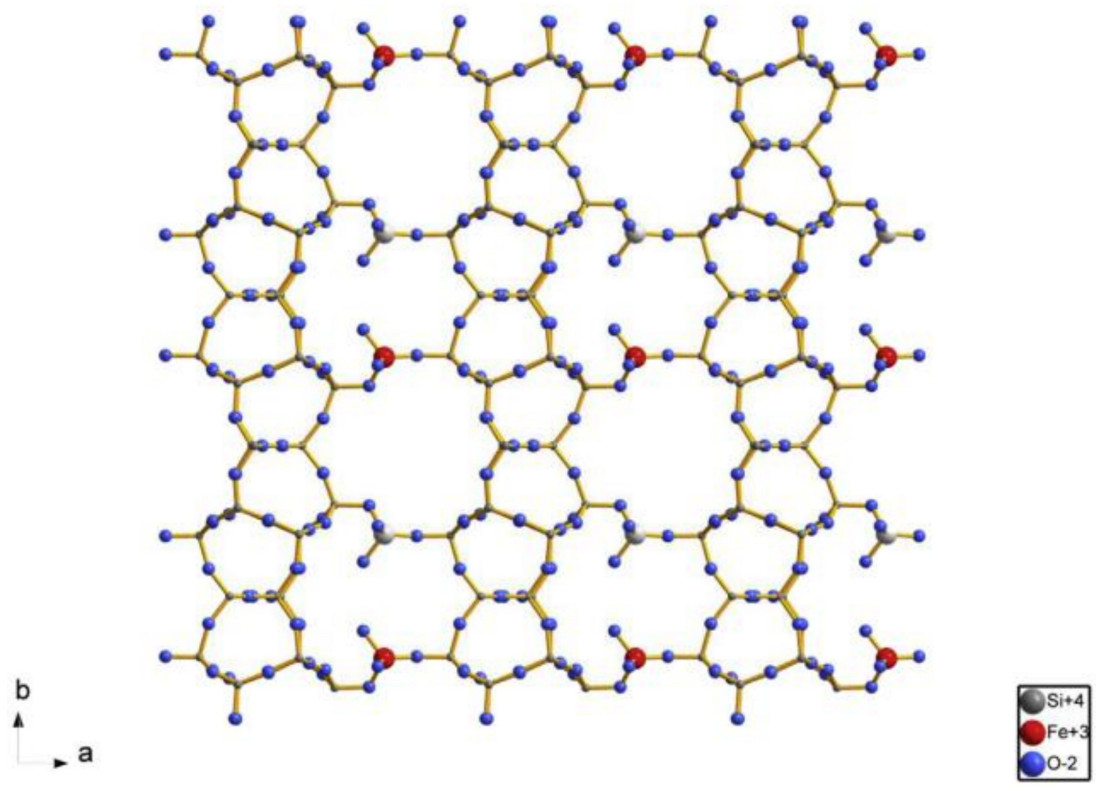

Figure 15. Projection along [001] of the framework of Fe-IEZ-CDO showing schematically the metal centers at every linker site. Reprinted with permission from ref. [66]. Copyright 2016, Elsevier.

\section{Catalytic Properties}

\subsection{Acidity Characterization}

The acidity of the materials changes significantly after inserting metal atoms. The Lewis-Bronsted acidity is determined by Fourier-transform infrared spectroscopy of pyridine (Py-FTIR). All catalysts are detected in $10 \mathrm{mg}$ sample tablets with a special shape. Figure 16 shows the difference spectra after adsorption of pyridine. The adsorption bands at 1455-1450, 1480-1490 and 1550-1545 $\mathrm{cm}^{-1}$ correspond to pyridine adsorbed at LewisBronsted acid sites $[76,95,96]$. Compared with the original 3D crystals, the intensity associated with Lewis-acid sites increases for IEZ samples, which contributes to the incorporation of metal species. Compared with Al-CDO, Fe-IEZ-CDO, and Fe-IEZ-Al-CDO in Figure 16, the absorbance increases significantly due to the contribution of Fe and $\mathrm{Al}$ species incorporated into the precursor layer. 


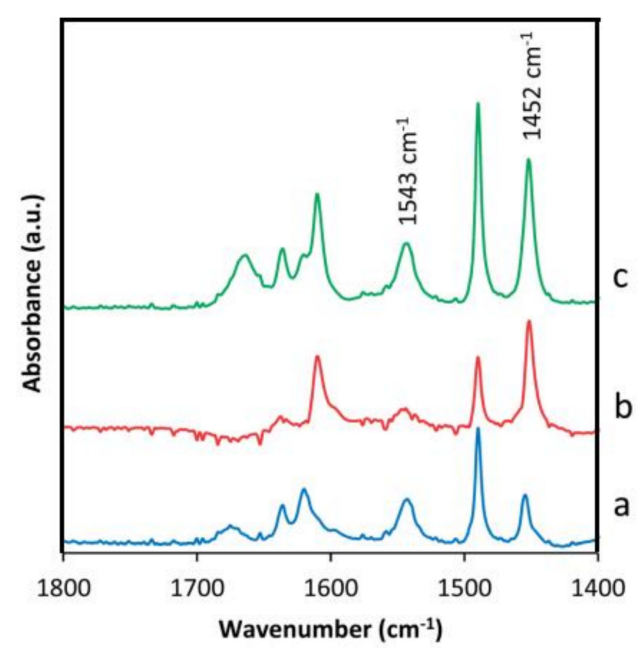

Figure 16. Different Py-FTIR spectra of adsorbed pyridine on (a) Al-CDO, (b) Fe-IEZ-CDO, (c) Fe-IEZAl-CDO. Reprinted with permission from ref. [65]. Copyright 2014, The Royal Society of Chemistry.

\subsection{Catalytic Measurements}

The IEZ material has larger pores than the 3D structure obtained by direct calcination and is expected to offer better catalytic activity [97-101]. Table 6 exhibits catalytic activity and selectivity in oxidation of cyclohexene over titanosilicates. IEZ-Ti-MWW has been widely accepted as an efficient catalyst in cyclohexene oxidation with $\mathrm{H}_{2} \mathrm{O}_{2}$ [102-105]. It is difficult for cyclohexene with a large dynamic diameter to penetrate the 10-MR window in 3D MWW. Expanding the interlayer space is the most effective way to make the Ti sites in the supercage serve as active sites for oxidizing large-volume substrate molecules. The phenomenon also occurs in Ti-CDO and IEZ-Ti-CDO materials [50]. For oxidizing cyclohexene, Ti-CDO samples have low conversion because of the inaccessibility for cyclohexene. Conversely, IEZ-Ti-CDO exhibits excellent activity.

Table 6. Catalytic activity and selectivity in oxidation of cyclohexene over titanosilicates.

\begin{tabular}{|c|c|c|c|c|c|}
\hline \multirow{2}{*}{ Catalyst } & \multirow{2}{*}{ Conversion } & \multirow{2}{*}{$\begin{array}{l}\text { TOF } \\
\left(h^{-1}\right)\end{array}$} & \multicolumn{2}{|c|}{ Selectivity } & \multirow{2}{*}{ Reference } \\
\hline & & & Epoxide & Others & \\
\hline Ti-MWW ${ }^{1}$ & 8.1 & / & 35.0 & 65.0 & \multirow{2}{*}{ [26] } \\
\hline IEZ-Ti-MWW ${ }^{1}$ & 21.2 & / & 90.8 & 9.2 & \\
\hline $\mathrm{Ti}^{-C D O}{ }^{2}$ & 4.2 & 19.1 & / & / & \multirow{2}{*}{ [40] } \\
\hline IEZ-Ti-CDO $^{2}$ & 14 & 63.9 & / & / & \\
\hline
\end{tabular}

${ }^{1}$ Reaction conditions: $60^{\circ} \mathrm{C}, 2 \mathrm{~h}, 50 \mathrm{mg}$ catalyst, $10 \mathrm{~mL}$ acetonitrile as solvent, $10 \mathrm{mmol}$ cyclohexene, $10 \mathrm{mmol}$ of $\mathrm{H}_{2} \mathrm{O}_{2} .{ }^{2}$ Reaction conditions: $60{ }^{\circ} \mathrm{C}, 4 \mathrm{~h}, 50 \mathrm{mg}$ catalyst, $10 \mathrm{~mL}$ methanol as solvent, $10 \mathrm{mmol}$ cyclohexene, $10 \mathrm{mmol}$ of $\mathrm{H}_{2} \mathrm{O}_{2}$.

In addition, the incorporation of metal species strongly increases the catalytic activity because the metal atoms provide active centers. The catalytic activity of expanded CDO materials is investigated in alkylation of toluene with benzyl chloride [65]. As shown in Figure 17, IEZ-CDO is not active for the alkylation reaction. Notably, Fe-IEZ-CDO and Fe-IEZ-Al-CDO offer significant benzyl chloride conversion. This result confirms that the incorporated $\mathrm{Fe}$ atoms play an important role in catalyzing this reaction. 


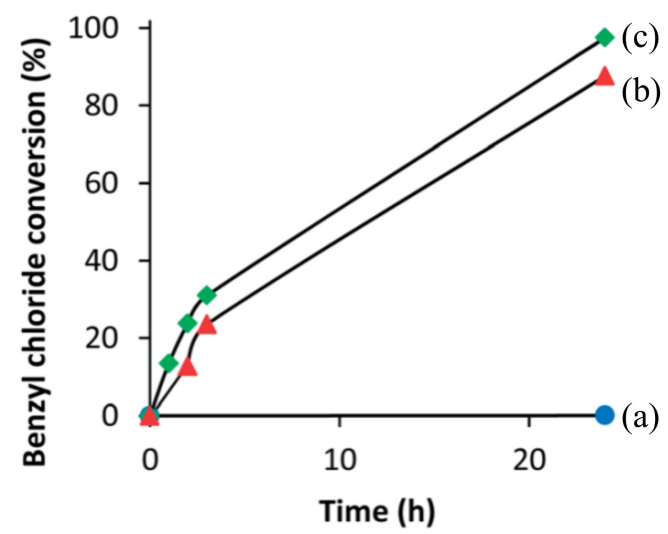

Figure 17. Benzyl chloride conversion in benzylation of toluene as a function of time at $403 \mathrm{~K}$ for (a) IEZ-Al-CDO, (b) Fe-IEZ-CDO, and (c) Fe-IEZ-Al-CDO. Reprinted with permission from ref. [65]. Copyright 2014, Royal Society of Chemistry.

\subsection{Adsorption of Metal Cations}

The IEZ materials have also been discussed for increased adsorption of metal cations (such as Ce) and enhanced activity. Roth and co-workers studied the MWW zeolite [106] and found the expansion of the interlayer distance increases would be accessible to these surface cavities and thus allow diffusion of ions. The IEZ-MWW samples form adsorbed twice as many cerium ions compared with the same Al content as MCM-22 (Table 7). The abundant adsorption of cerium species of Ce/IEZ-MWW samples enables higher CO oxidation. These results confirm the IEZ materials provide great potential opportunities in the catalytic applications.

Table 7. Basic properties of the studied materials. Reprinted with permission from ref. [108]. Copyright 2014, Royal Society of Chemistry.

\begin{tabular}{|c|c|c|c|c|c|}
\hline Zeolite & $\begin{array}{l}\text { Si/Al, } \\
\text { XRF }\end{array}$ & $\begin{array}{c}\text { BET, } \\
\mathrm{m}^{2} \mathrm{~g}^{-1}\end{array}$ & $\begin{array}{c}\text { Ce(La), } \\
\text { wt } \%\end{array}$ & $\begin{array}{c}\text { BAS }^{1} \\
\mu \mathrm{mol} \mathrm{g}^{-1}\end{array}$ & $\begin{array}{c}\text { LAS }^{2} \\
\mu \mathrm{mol} \mathrm{g}^{-1}\end{array}$ \\
\hline MCM-22 & 13 & 436 & - & 664 & 46 \\
\hline IEZ-MWW & 13 & 531 & - & 621 & 112 \\
\hline $\mathrm{Ce} / \mathrm{MCM}-22^{3}$ & 13 & - & 0.40 & 714 & 95 \\
\hline Ce/IEZ-MWW 3 & 13 & - & 0.88 & 357 & 70 \\
\hline
\end{tabular}

${ }^{1}$ BAS refers to Bronsted acid site concentrations. ${ }^{2}$ LAS refers to Lewis acid site concentrations. ${ }^{3}$ The cerium here is adsorption by ion-exchange.

\section{The ADOR Synthesis of New Zeolites}

Besides the direct synthesis of layered zeolites, a special top and down methodology named ADOR is designed (assembly-disassembly-organisation-reassembly) [107-109]. Typically, the new structures PCR and OKO have been synthesized by this method (Figure 18). In order to obtain the lamellar precursors, IPC-1P, original zeolite UTL samples are treated in a Walker-type multi-anvil apparatus at $1 \mathrm{GPa}$ with heating $200{ }^{\circ} \mathrm{C}$ for $2 \mathrm{~min}$. Through controlled organisation of IPC-1P, one can prepare a series of materials (IPC-2, IPC-4, IPC-6, IPC-7) [109-113]. When the organization agents refer to the silane type (diethoxydimethylsilane, DMDOES), the silanol groups connect to the surface of IPC-1P and interlayer expand the distance. After intercalation of organizing agent, the obtained OKO framework, IPC-2, possess 12 and 10-ring channels. This method has been successfully applied for other zeolite SAZ [114]. 


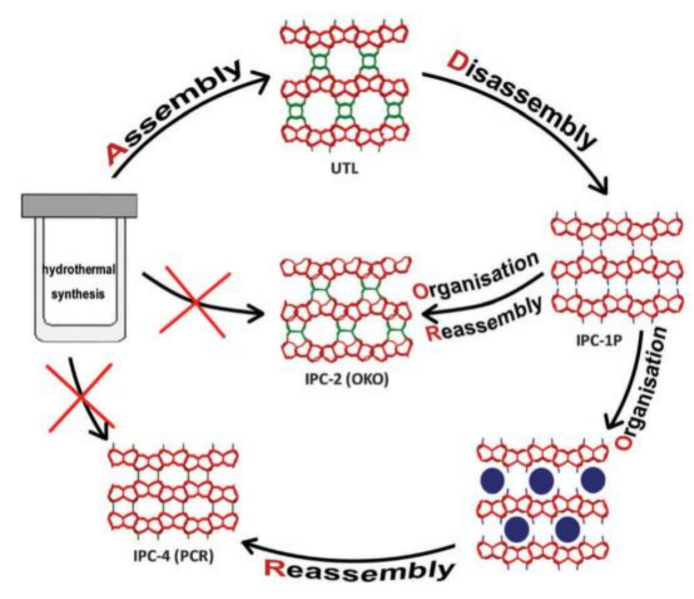

Figure 18. The ADOR method in a cycle scheme demonstrating the mechanism for the synthesis of two novel zeolites, IPC-2 (OKO) and IPC-4 (PCR), in which of them have not been sofa prepared by direct hydrothermal synthesis. The interlay bonds are highlighted in green, and the terminal silanol groups in blue. Reprinted with permission from ref. [8]. Copyright 2015, Royal Society of Chemistry.

\section{Conclusions}

This review briefly summarizes the novel zeolite structures constructed from the lamellar precursor zeolites MWW, RUB-36, PREFER, Nu-6(1), COK-5, and PLS-1 via interlayer expansion, with silicon species or metal species inserted and bonded to Si atoms in the lamellar layer. A variety of measurements could confirm that functional linker sites connected to Si atoms in the lamellar layer. The resulting materials with ordered crystalline structure have larger pore windows and tunable wettability, which is beneficial for varying the catalytic function. The incorporation of metal atoms provides an extra source of catalysts for large molecules. The use of interlayer-expansion agents to connect layered silicates proves to be a general route for these novel zeolite structures. This method and the stable materials obtained could have important industrial applications in the near future.

Author Contributions: Conceptualization, C.B. and X.L.; Investigation, Y.Y., J.Z. and W.Z.; Review \& Editing, L.Z. and J.Q. All authors have read and agreed to the published version of the manuscript.

Funding: This research was funded by the National Nature Science Foundation of China (21902065, 21802053), Zhejiang Provincial Natural Science Foundation of China (LGF19E080007) and Jinhua Science and Technology Bureau (2019-4-165, 2019-4-168, 2021-4-333).

Institutional Review Board Statement: Not applicable.

Informed Consent Statement: Not applicable.

Data Availability Statement: Data available in a publicly accessible repository.

Conflicts of Interest: The authors declare no conflict of interest.

Sample Availability: Samples of the compounds are not available from the authors.

\section{References}

1. Pfriem, N.; Hintermeier, P.H.; Eckstein, S.; Kim, S.; Liu, Q.; Shi, H.; Milakovic, L.; Liu, Y.; Haller, G.L.; Baráth, E.; et al. Role of the ionic environment in enhancing the activity of reacting molecules in zeolite pores. Science 2021, 372, 952-957. [CrossRef]

2. Zhou, Y.; Zhang, J.; Wang, L.; Cui, X.; Liu, X.; Wong, S.S.; An, H.; Yan, N.; Xie, J.; Yu, C.; et al. Self-assembled iron-containing mordenite monolith for carbon dioxide sieving. Science 2021, 373, 315-320. [CrossRef] [PubMed]

3. Chi, X.; Li, M.; Di, J.; Bai, P.; Song, L.; Wang, X.; Li, F.; Liang, S.; Xu, J.; Yu, J. A highly stable and flexible zeolite electrolyte solid-state Li-air battery. Nat. Cell Biol. 2021, 592, 551-557. [CrossRef]

4. Shen, B.; Chen, X.; Wang, H.; Xiong, H.; Bosch, E.G.T.; Lazić, I.; Cai, D.; Qian, W.; Jin, S.; Liu, X.; et al. A single-molecule van der Waals compass. Nat. Cell Biol. 2021, 592, 541-544. [CrossRef] 
5. Lee, H.; Shin, J.; Lee, K.; Choi, H.J.; Mayoral, A.; Kang, N.Y.; Hong, S.B. Synthesis of thermally stable SBT and SBS/SBT intergrowth zeolites. Science 2021, 373, 104-107. [CrossRef]

6. Davis, M.E. Ordered porous materials for emerging applications. Nat. Cell Biol. 2002, 417, 813-821. [CrossRef]

7. Marler, B.; Ströter, N.; Gies, H. The structure of the new pure silica zeolite RUB-24, Si32O64, obtained by topotactic condensation of the intercalated layer silicate RUB-18. Microporous Mesoporous Mater. 2005, 83, 201-211. [CrossRef]

8. Eliasova, P.; Opanasenko, M.; Wheatley, P.S.; Shamzhy, M.; Mazur, M.; Nachtigall, P.; Roth, W.J.; Morris, R.E.; Cejka, J. The ADOR mechanism for the synthesis of new zeolites. Chem. Soc. Rev. 2015, 44, 7177-7206. [CrossRef]

9. Davis, M.E.; Lobo, R. Zeolite and molecular sieve synthesis. Chem. Mater. 1992, 4, 756-768. [CrossRef]

10. Xu, H.; Zhu, J.; Zhu, L.; Zhou, E.; Shen, C. Advances in the Synthesis of Ferrierite Zeolite. Molecules 2020, 25, 3722. [CrossRef]

11. Xiao, F.-S.; Meng, X. (Eds.) Green chemistry and sustainable technology. In Zeolites in Sustainable Chemistry: Synthesis, Characterization and Catalytic Applications; Springer: Berlin/Heidelberg, Germany, 2016.

12. Oumi, Y.; Takeoka, T.; Ikeda, T.; Yokoyama, T.; Sano, T. Convenient conversion of crystalline layered silicate octosilicate into RWR-type zeolite by acetic acid intercalation. New J. Chem. 2007, 31, 593-597. [CrossRef]

13. Ren, L.; Guo, Q.; Orazov, M.; Xu, D.; Politi, D.; Kumar, P.; Alhassan, S.M.; Mkhoyan, K.; Sidiras, D.; Davis, M.E.; et al. Pillared Sn-MWW Prepared by a Solid-State-Exchange Method and its Use as a Lewis Acid Catalyst. ChemCatChem 2016, 8, 1274-1278. [CrossRef]

14. Roth, W.J.; Čejka, J.; Millini, R.; Montanari, E.; Gil, B.; Kubu, M. Swelling and Interlayer Chemistry of Layered MWW Zeolites MCM-22 and MCM-56 with High Al Content. Chem. Mater. 2015, 27, 4620-4629. [CrossRef]

15. Zanardi, S.; Alberti, A.; Cruciani, G.; Corma, A.; Fornes, V.; Brunelli, M. Crystal Structure Delamination of Zeolite Nu-6(2) and Its Layered Precursor Nu-6(1). Angew. Chem. Int. Ed. 2004, 43, 4933-4937. [CrossRef]

16. Wu, P.; Nuntasri, D.; Ruan, J.; Liu, Y.; He, M.; Fan, W.; Terasaki, A.O.; Tatsumi, T. Delamination of Ti-MWW and High Efficiency in Epoxidation of Alkenes with Various Molecular Sizes. J. Phys. Chem. B 2004, 108, 19126-19131. [CrossRef]

17. Wang, Y.X.; Gies, H.; Lin, J.H. Crystal Structure of the New Layer Silicate RUB-39 and Its Topotactic Condensation to a Microporous Zeolite with Framework Type RRO. Chem. Mater. 2007, 19, 4181-4188. [CrossRef]

18. Wang, Y.X.; Gies, H.; Marler, B.; Müller, U. Synthesis and Crystal Structure of Zeolite RUB-41 Obtained as Calcination Product of a Layered Precursor: A Systematic Approach to a New Synthesis Route. Chem. Mater. 2005, 17, 43-49. [CrossRef]

19. Gies, H.; Müller, U.; Yilmaz, B.; Tatsumi, T.; Xie, B.; Xiao, F.-S.; Bao, X.; Zhang, W.; De Vos, D. Interlayer Expansion of the Layered Zeolite Precursor RUB-39: A Universal Method To Synthesize Functionalized Microporous Silicates. Chem. Mater. 2011, 23, 2545-2554. [CrossRef]

20. Kiba, S.; Itagaki, T.; Nakato, T.; Kuroda, K. Interlayer modification of a layered H-octosilicate (H-RUB-18) with methanol: Formation of a highly ordered organosilicate nanohybrid. J. Mater. Chem. 2010, 20, 3202-3210. [CrossRef]

21. Corma, A.; Fornes, V.; Pergher, S.; Maesen, T.L.M.; Buglass, J.G. Delaminated zeolite precursors as selective acidic catalysts. Nat. Cell Biol. 1998, 396, 353-356. [CrossRef]

22. Marler, B.; Gies, H. Hydrous layer silicates as precursors for zeolites obtained through topotactic condensation: A review. Eur. J. Miner. 2012, 24, 405-428. [CrossRef]

23. Blake, A.J.; Franklin, K.R.; Lowe, B.M. Preparation and properties of piperazine silicate (EU-19) and s silica polymorph (EU-20). J. Chem. Soc. Dalton Trans. 1988, 2513-2517. [CrossRef]

24. Dorset, D.L.; Kennedy, G.J. Crystal Structure of MCM-65: An Alternative Linkage of Ferrierite Layers. J. Phys. Chem. B 2004, 108, 15216-15222. [CrossRef]

25. Ikeda, T.; Akiyama, Y.; Oumi, Y.; Kawai, A.; Mizukami, F. The Topotactic Conversion of a Novel Layered Silicate into a New Framework Zeolite. Angew. Chem. Int. Ed. 2004, 43, 4892-4896. [CrossRef] [PubMed]

26. Knight, L.M.; Miller, M.A.; Koster, S.C.; Gatter, M.G.; Benin, A.I.; Willis, R.R.; Lewis, G.J.; Broach, R.W. UZM-13, UZM-17, UZM-19 and UZM-25: Synthesis and structure of new layered precursors and a zeolite discovered via combinatorial chemistry techniques. Stud. Surf. Sci. Catal. 2007, 170A, 338-346. [CrossRef]

27. Marler, B.; Wang, Y.; Song, J.; Gies, H. RUB-36, a new layer silicate with ferrierite-type layers which can be condensated to form a highly ordered CDO-type zeolite. Book of Abstracts. In Proceedings of the 15th International Zeolite Conference, Beijing, China, 12-17 August 2007; pp. 599-600.

28. Ikeda, T.; Kayamori, S.; Mizukami, F. Synthesis and crystal structure of layered silicate PLS-3 and PLS-4 as a topotactic zeolite precursor. J. Mater. Chem. 2009, 19, 5518-5525. [CrossRef]

29. Schreyeck, L.; Caullet, P.; Mougenel, J.; Guth, J.; Marler, B. PREFER: A new layered (alumino) silicate precursor of FER-type zeolite. Microporous Mater. 1996, 6, 259-271. [CrossRef]

30. Leonowicz, M.E.; Lawton, J.A.; Lawton, S.L.; Rubin, M.K. MCM-22: A Molecular Sieve with Two Independent Multidimensional Channel Systems. Science 1994, 264, 1910-1913. [CrossRef] [PubMed]

31. Camblor, M.; Corma, A.; Díaz-Cabañas, M.-J.; Baerlocher, C. Synthesis and Structural Characterization of MWW Type Zeolite ITQ-1, the Pure Silica Analog of MCM-22 and SSZ-25. J. Phys. Chem. B 1998, 102, 44-51. [CrossRef]

32. Shamzhy, M.; Gil, B.; Opanasenko, M.; Roth, W.J.; Čejka, J. MWW and MFI Frameworks as Model Layered Zeolites: Structures, Transformations, Properties, and Activity. ACS Catal. 2021, 11, 2366-2396. [CrossRef]

33. Moteki, T.; Chaikittisilp, W.; Shimojima, A.; Okubo, T. Silica sodalite without occluded organic matters by topotactic conversion of lamellar precusor. J. Am. Chem. Soc. 2008, 130, 15780-15781. [CrossRef] 
34. Henkelis, S.E.; Mazur, M.; Rice, C.M.; Wheatley, P.S.; Ashbrook, S.E.; Morris, R.E. Kinetics and Mechanism of the Hydrolysis and Rearrangement Processes within the Assembly-Disassembly-Organization-Reassembly Synthesis of Zeolites. J. Am. Chem. Soc. 2019, 141, 4453-4459. [CrossRef] [PubMed]

35. Banno, S.; Komura, K. Large Crystals Synthesis of Siliceous Layered Zeolitic PLS-1 and CDS-1 Zeolite by Dry Gel Conversion. Method Cryst. Res. Technol. 2018, 53, 1800036. [CrossRef]

36. Wu, P.; Ruan, J.; Wang, L.; Wu, L.; Wang, Y.; Liu, Y.; Fan, W.; He, M.; Terasaki, O.; Tatsumi, T. Methodology for Synthesizing Crystalline Metallosilicates with Expanded Pore Windows Through Molecular Alkoxysilylation of Zeolitic Lamellar Precursors. J. Am. Chem. Soc. 2008, 130, 8178-8187. [CrossRef] [PubMed]

37. Roth, W.; Nachtigall, P.; Morris, R.; Čejka, J. Two-Dimensional Zeolites: Current Status and Perspectives. Chem. Rev. 2014, 114, 4807-4837. [CrossRef] [PubMed]

38. Fan, W.; Wu, P.; Namba, S.; Tatsumi, T. A Titanosilicate That Is Structurally Analogous to an MWW-Type Lamellar Precursor. Angew. Chem. Int. Ed. 2003, 43, 236-240. [CrossRef] [PubMed]

39. Yokoi, T.; Tatsumi, T. Interlayer Expansion of the Layered Zeolites. In Zeolites in Sustainable Chemistry; Springer: Berlin/Heidelberg, Germany, 2016; pp. 77-100.

40. Bian, C.; Wu, Q.; Zhang, J.; Chen, F.; Pan, S.; Wang, L.; Meng, X.; Müller, U.; Feyen, M.; Yilmaz, B.; et al. A new zeolite formed from interlayer expansion of the precursor COK-5. Microporous Mesoporous Mater. 2015, 214, 204-209. [CrossRef]

41. Martínez-Franco, R.; Paris, C.; Martínez-Triguero, J.; Moliner, M.; Corma, A. Direct synthesis of the aluminosilicate form of the small pore CDO zeolite with novel OSDAs and the expanded polymorphs. Microporous Mesoporous Mater. 2017, 246, 147-157. [CrossRef]

42. Yang, B.; Jiang, J.-G.; Zhang, K.; Wu, P. Synthesis of Novel Titanosilicate Catalysts by Simultaneous Isomorphous Substitution and Interlayer Expansion of Zeolitic Layered Silicates. Chem. Mater. 2016, 28, 5295-5303. [CrossRef]

43. Kawai, A.; Urabe, Y.; Itoh, T.; Mizukami, F. Immobilization of lysozyme on the layered silicate RUB-15. Mater. Chem. Phys. 2010, 122, 269-272. [CrossRef]

44. Schulman, E.; Wu, W.; Liu, D. Two-Dimensional Zeolite Materials: Structural and Acidity Properties. Materials 2020, 13, 1822. [CrossRef] [PubMed]

45. Millini, R.; Carluccio, L.C.; Carati, A.; Bellussi, G.; Perego, C.; Cruciani, G.; Zanardi, S. ERS-12: A new layered tetramethylammonium silicate composed by ferrierite layers. Microporous Mesoporous Mater. 2004, 74, 59-71. [CrossRef]

46. Juttu, G.G.; Lobo, R.F. Characterization and catalytic properties of MCM-56 and MCM-22 zeolites. Microporous Mesoporous Mater. 2000, 40, 9-23. [CrossRef]

47. Inagaki, S.; Yokoi, T.; Kubota, Y.; Tatsumi, T. Unique adsorption properties of organic-inorganic hybrid zeolite IEZ-1 with dimethylsilylene moieties. Chem. Commun. 2007, 5188-5190. [CrossRef]

48. Ruan, J.; Wu, P.; Slater, B.; Terasaki, O. Structure Elucidation of the Highly Active Titanosilicate Catalyst Ti-YNU-1. Angew. Chem. Int. Ed. 2005, 44, 6719-6723. [CrossRef]

49. Bian, C.; Wang, X.; Yu, L.; Zhang, F.; Zhang, J.; Fei, Z.; Qiu, J.; Zhu, L. Generalized Methodology for Inserting Metal Heteroatoms into the Layered Zeolite Precursor RUB-36 by Interlayer Expansion. Crystals 2020, 10, 530. [CrossRef]

50. Xiao, F.-S.; Xie, B.; Zhang, H.; Wang, L.; Meng, X.; Zhang, W.; Bao, X.; Yilmaz, B.; Müller, U.; Gies, H.; et al. Interlayer-Expanded Microporous Titanosilicate Catalysts with Functionalized Hydroxyl Groups. Chem CatChem 2011, 3, 1442-1446. [CrossRef]

51. Gies, H.; Feyen, M.; De Baerdemaeker, T.; De Vos, D.E.; Yilmaz, B.; Müller, U.; Meng, X.; Xiao, F.-S.; Zhang, W.; Yokoi, T.; et al. Interlayer expansion using metal-linker units: Crystalline microporous silicate zeolites with metal centers on specific framework sites. Microporous Mesoporous Mater. 2016, 222, 235-240. [CrossRef]

52. Gies, H.; Müller, U.; Yilmaz, B.; Feyen, M.; Tatsumi, T.; Imai, H.; Zhang, H.; Xie, B.; Xiao, F.-S.; Bao, X.; et al. Interlayer Expansion of the Hydrous Layer Silicate RUB-36 to a Functionalized, Microporous Framework Silicate: Crystal Structure Analysis and Physical and Chemical Characterization. Chem. Mater. 2012, 24, 1536-1545. [CrossRef]

53. Yilmaz, B.; Müller, U.; Feyen, M.; Zhang, H.; Xiao, F.-S.; De Baerdemaeker, T.; Tijsebaert, B.; Jacobs, P.; De Vos, D.; Zhang, W.; et al. New zeolite Al-COE-4: Reaching highly shape-selective catalytic performance through interlayer expansion. Chem. Commun. 2012, 48, 11549-11551. [CrossRef] [PubMed]

54. Jiang, J.-G.; Jia, L.; Yang, B.; Xu, H.; Wu, P. Preparation of Interlayer-Expanded Zeolite from Lamellar Precursor Nu-6(1) by Silylation. Chem. Mater. 2013, 25, 4710-4718. [CrossRef]

55. Bian, C.; Wu, Q.; Zhang, J.; Pan, S.; Wang, L.; Meng, X.; Xiao, F.-S. Interlayer expansion of the layered zeolite precursor COK-5 with $\mathrm{Sn}(\mathrm{acac})_{2} \mathrm{Cl}_{2}$. J. Energy Chem. 2015, 24, 642-645. [CrossRef]

56. Ruan, J.; Wu, P.; Slater, B.; Zhao, Z.; Wu, L.; Terasaki, O. Structural Characterization of Interlayer Expanded Zeolite Prepared From Ferrierite Lamellar Precursor. Chem. Mater. 2009, 21, 2904-2911. [CrossRef]

57. Yang, B.-T.; Wu, P. Post-synthesis and catalytic performance of FER type sub-zeolite Ti-ECNU-8. Chin. Chem. Lett. 2014, 25, 1511-1514. [CrossRef]

58. Liao, X.; Chen, G.; Liu, G.; Sun, L.; Huo, W.; Zhang, W.; Jia, M. Synthesis, characterization of COK-5 with different Si/Al ratios and their catalytic properties for the tert-butylation of phenol. Microporous Mesoporous Mater. 2009, 124, 210-217. [CrossRef]

59. Kirschhock, C.; Bons, A.-J.; Mertens, M.; Ravishankar, R.; Mortier, W.; Jacobs, P.; Martens, J. Characterization of COK-5, Member of a New Family of Zeolite Material with Multiple Channel Systems. Chem. Mater. 2005, 17, 5618-5624. [CrossRef] 
60. Wu, P.; Tatsumi, T. A New Generation of Titanosilicate Catalyst: Preparation and Application to Liquid-Phase Epoxidation of Alkenes. Catal. Surv. Asia 2004, 8, 137-148. [CrossRef]

61. Wu, P.; Tatsumi, T.; Komatsu, A.T.; Yashima, T. A Novel Titanosilicate with MWW Structure. I. Hydrothermal Synthesis, Elimination of Extraframework Titanium, and Characterizations. J. Phys. Chem. B 2001, 105, 2897-2905. [CrossRef]

62. Xu, L.; Sun, J. Recent Advances in the Synthesis and Application of Two-Dimensional Zeolites. Adv. Energy Mater. 2016, 6, 1600441. [CrossRef]

63. Burton, A.; Accardi, R.J.; Lobo, R.F.; Falcioni, M.; Deem, M.W. MCM-47: A Highly Crystalline Silicate Composed of HydrogenBonded Ferrierite Layers. Chem. Mater. 2000, 12, 2936-2942. [CrossRef]

64. Xu, H.; Yang, B.; Jiang, J.-G.; Jia, L.; He, M.; Wu, P. Post-synthesis and adsorption properties of interlayer-expanded PLS-4 zeolite. Microporous Mesoporous Mater. 2013, 169, 88-96. [CrossRef]

65. De Baerdemaeker, T.; Gies, H.; Yilmaz, B.; Müller, U.; Feyen, M.; Xiao, F.-S.; Zhang, W.; Yokoi, T.; Bao, X.; De Vos, D.E. A new class of solid Lewis acid catalysts based on interlayer expansion of layered silicates of the RUB-36 type with heteroatoms. J. Mater. Chem. A 2014, 2, 9709-9717. [CrossRef]

66. Fan, W.; Wu, P.; Namba, S.; Tatsumi, T. Synthesis and catalytic properties of a new titanosilicate molecular sieve with the structure analogous to MWW-type lamellar precursor. J. Catal. 2006, 243, 183-191. [CrossRef]

67. Verheyen, E.; Joos, L.; Van Havenbergh, K.; Breynaert, E.; Kasian, N.; Gobechiya, E.; Houthoofd, K.; Martineau-Corcos, C.; Hinterstein, M.; Taulelle, F.; et al. Design of zeolite by inverse sigma transformation. Nat. Mater. 2012, 11, 1059-1064. [CrossRef]

68. Roth, W.; Nachtigall, P.; Morris, R.; Wheatley, P.S.; Seymour, V.R.; Ashbrook, S.; Chlubná, P.; Grajciar, L.; Položij, M.; Zukal, A.; et al. A family of zeolites with controlled pore size prepared using a top-down method. Nat. Chem. 2013, 5, 628-633. [CrossRef] [PubMed]

69. Tijsebaert, B.; Henry, M.; Gies, H.; Xiao, F.-S.; Zhang, W.; Bao, X.; Imai, H.; Tatsumi, T.; Müller, U.; Yilmaz, B.; et al. Exploring the void structure and activity of RUB-39 based expanded materials using the hydroconversion of decane. J. Catal. 2011, 282, 47-53. [CrossRef]

70. Mochizuki, D.; Shimojima, A.; Kuroda, K. Formation of a New Crystalline Silicate Structure by Grafting Dialkoxysilyl Groups on Layered Octosilicate. J. Am. Chem. Soc. 2002, 124, 12082-12083. [CrossRef] [PubMed]

71. Lawton, S.L.; Fung, A.S.; Kennedy, G.J.; Alemany, L.B.; Chang, C.D.; Hatzikos, G.H.; Lissy, D.N.; Rubin, M.K.; Timken, H.-K.C.; Steuernagel, A.S.; et al. Zeolite MCM-49: A Three-Dimensional MCM-22 Analogue Synthesized byin SituCrystallization. J. Phys. Chem. 1996, 100, 3788-3798. [CrossRef]

72. Joo, J.; Hyeon, T.; Hyeon-Lee, J. Fabrication of novel mesoporous dimethylsiloxane-incorporated silicas. Chem. Commun. 2000, 1487-1488. [CrossRef]

73. Yamamoto, K.; Nohara, Y.; Domon, Y.; Takahashi, Y.; Sakata, Y.; Plévert, J.; Tatsumi, T. Organic-Inorganic Hybrid Zeolites with Framework Organic Groups. Chem. Mater. 2005, 17, 3913-3920. [CrossRef]

74. Inagaki, S.; Tatsumi, T. Vapourr-phase silylation for the construction of monomeric silica puncheons in the interlayer micropores of Al-MWW layered precusor. Chem. Commun. 2009, 2583-2585. [CrossRef]

75. Fan, W.; Wei, S.; Yokoi, T.; Inagaki, S.; Li, J.; Wang, J.; Kondo, J.; Tatsumi, T. Synthesis, characterization, and catalytic properties of H-Al-YNU-1 and H-Al-MWW with different Si/ Al ratios. J. Catal. 2009, 266, 268-278. [CrossRef]

76. Vicente, G.; Melero, J.A.; Morales, G.; Paniagua, M.; Martín, E. Acetalisation of bio-glycerol with acetone to produce solketal over sulfonic mesostructured silicas. Green Chem. 2010, 12, 899-907. [CrossRef]

77. Wang, L.; Zhang, J.; Wang, X.; Zhang, B.; Ji, W.; Meng, X.; Li, J.; Su, D.S.; Bao, X.; Xiao, F.-S. Creation of Brønsted acid sites on Sn-based solid catalysts for the conversion of biomass. J. Mater. Chem. A 2014, 2, 3725-3729. [CrossRef]

78. da Silva, C.X.A.; Goncalves, V.L.C.; Mota, C.J.A. Water-tolerant zeolite catalyst for the acetalisation of glycerol. Green Chem. 2009, 11, 38-41. [CrossRef]

79. Zi, W.-W.; Zhang, J.; Cai, X.-S.; Jiao, F.; Du, H.-B. Synthesis and characterization of a layered aluminosilicate NUD-11 and its transformation to a 3D stable zeolite. Dalton Trans. 2020, 49, 11682-11688. [CrossRef]

80. Woolery, G.; Alemany, L.; Dessau, R.; Chester, A. Spectroscopic evidence for the presence of internal silanols in highly siliceous ZSM-5. Zeolites 1986, 6, 14-16. [CrossRef]

81. Yang, B.; Cui, T.; Chen, Y.; Wen, L. Preparation and catalytic properties of a novel aluminosilicate zeolite with intersecting 14*12-Ring pore sizes. Microporous Mesoporous Mater. 2020, 303, 110251. [CrossRef]

82. Engelhardt, G.; Michel, D. High Resolution Solid State NMR of Silicates and Zeolites; Wiley: New York, NY, USA, 1987.

83. Zhao, Z.; Li, X.; Li, S.; Xu, S.; Bao, X.; Bilge, Y.; Andrei-Nicolae, P.; Ulrich, M.; Zhang, W. Structural investigation of interlayerexpanded zeolite by hyperpolarized 129Xe and 1H NMR spectroscopy. Microporous Mesoporous Mater. 2019, $288,109555$. [CrossRef]

84. Leroy, C.; Bryce, D.L. Recent advances in solid-state nuclear magnetic resonance spectroscopy of exotic nuclei. Prog. Nucl. Magn Reson. Spectrosc. 2018, 109, 160-199. [CrossRef] [PubMed]

85. Umamaheswari, V.; Böhlmann, W.; Pöppl, A.; Vinu, A.; Hartmann, M. Spectroscopic characterization of iron-containing MCM-58. Microporous Mesoporous Mater. 2006, 89, 47-57. [CrossRef]

86. Hensen, E.; Zhu, Q.; Janssen, R.; Magusin, P.; Kooyman, P.; van Santen, R. Selective oxidation of benzene to phenol with nitrous oxide over MFI zeolites: 1. On the role of iron and aluminum. J. Catal. 2005, 233, 123-135. [CrossRef] 
87. Pérez-Ramírez, J.; Groen, J.; Brückner, A.; Kumar, M.; Bentrup, U.; Debbagh, M.; Villaescusa, L. Evolution of isomorphously substituted iron zeolites during activation: Comparison of Fe-beta and Fe-ZSM-5. J. Catal. 2005, 232, 318-334. [CrossRef]

88. Bordiga, S.; Buzzoni, R.; Geobaldo, F.; Lamberti, C.; Giamello, E.; Zecchina, A.; Leofanti, G.; Petrini, G.; Tozzola, G.; Vlaic, G. Structure and Reactivity of Framework and Extraframework Iron in Fe-Silicalite as Investigated by Spectroscopic and Physicochemical Methods. J. Catal. 1996, 158, 486-501. [CrossRef]

89. Kumar, M.S.; Schwidder, M.; Grunert, W.; Brückner, A. On the nature of different iron sites and their catalytic role in Fe-ZSM-5 DeNOx catalysts: New insights by a combined EPR and UV/VIS spectroscopic approach. J. Catal. 2004, 227, 384-397. [CrossRef]

90. Tang, B.; Dai, W.; Wu, G.; Guan, N.; Li, L.; Hunger, M. Improved Postsynthesis Strategy to Sn-Beta Zeolites as Lewis Acid Catalysts for the Ring-Opening Hydration of Epoxides. ACS Catal. 2014, 4, 2801-2810. [CrossRef]

91. Pachamuthu, M.P.; Shanthi, K.; Luque, R.; Ramanathan, A. SnTUD-1: A solid acid catalyst for three component coupling reactions at room temperature. Green Chem. 2013, 15, 2158. [CrossRef]

92. Luo, H.Y.; Bui, L.; Gunther, W.R.; Min, E.; Román-Leshkov, Y. Synthesis and Catalytic Activity of Sn-MFI Nanosheets for the Baeyer-Villiger Oxidation of Cyclic Ketones. ACS Catal. 2012, 2, 2695-2699. [CrossRef]

93. Niphadkar, P.S.; Joshi, P.N. Oxyanion-Induced Hydrothermal Crystallization of Sn-Beta Molecular Sieve in Fluoride Medium from Unseeded Gel. Adv. Porous Mater. 2015, 2, 204-211. [CrossRef]

94. Li, H.; Wang, J.; Zhou, D.; Tian, D.; Shi, C.; Müller, U.; Feyen, M.; Gies, H.; Xiao, F.-S.; De Vos, D.; et al. Structural stability and Lewis acidity of tetravalent Ti, Sn, or Zr-linked interlayer-expanded zeolite COE-4: A DFT study. Microporous Mesoporous Mater. 2015, 218, 160-166. [CrossRef]

95. Khandan, N.; Kazemeini, M.; Aghaziarati, M. Determining an optimum catalyst for liquid-phase dehydration of methanol to dimethyl ether. Appl. Catal. A Gen. 2008, 349, 6-12. [CrossRef]

96. Mallesham, B.; Sudarsanam, P.; Reddy, B.M. Eco-friendly synthesis of bio-additive fuels from renewable glycerol using nanocrystalline SnO2-based solid acids. Catal. Sci. Technol. 2014, 4, 803-813. [CrossRef]

97. De Baerdemaeker, T.; Vandebroeck, W.; Gies, H.; Yilmaz, B.; Müller, U.; Feyen, M.; De Vos, D. Shape-selective organic-inorganic zeolitic catalysts prepared via interlayer expansion. Catal. Today 2014, 235, 169-175. [CrossRef]

98. Ge, P.; Luo, Y.; Huang, Q.; Chen, X.; Hu, H. Synthesis of ERB-1 by a steam-environment crystallization method and further application in the post-synthesis of Ti-MWW zeolite. Appl. Catal. A Gen. 2018, 564, 218-225. [CrossRef]

99. Inagaki, S.; Imai, H.; Tsujiuchi, S.; Yakushiji, H.; Yokoi, T.; Tatsumi, T. Enhancement of catalytic properties of interlayer-expanded zeolite Al-MWW via the control of interlayer silylation conditions. Microporous Mesoporous Mater. 2011, 142, 354-362. [CrossRef]

100. Yang, B.; Cui, T.; Zhou, Y. Preparation of an extra-large pore titanosilicate with $14 \times 12$-ring channels and its catalytic performance in epoxidation. J. Porous Mater. 2021, 28, 171-181. [CrossRef]

101. Yang, B.; Jiang, J.-G.; Xu, H.; Liu, Y.; Peng, H.; Wu, P. Selective skeletal isomerization of 1-butene over FER-type zeolites derived from PLS-3 lamellar precursors. Appl. Catal. A Gen. 2013, 455, 107-113. [CrossRef]

102. Kim, T.-K.; Yang, S.-T.; Park, D.R.; Song, I.K.; Jung, K.-E.; Ahn, W.-S. Ti-MWW Synthesis and Catalytic Applications in Partial Oxidation Reactions. Top. Catal. 2010, 53, 470-478. [CrossRef]

103. Yoshioka, M.; Yokoi, T.; Tatsumi, T. Effectiveness of the reversible structural conversion of MWW zeolite for preparation of interlayer-expanded Ti-MWW with high catalytic performance in olefin epoxidation. Microporous Mesoporous Mater. 2014, 200, 11-18. [CrossRef]

104. Přech, J. Catalytic performance of advanced titanosilicate selective oxidation catalysts: A review. Catal. Rev. 2018, 60, 71-131. [CrossRef]

105. Wu, P.; Kubota, Y.; Yokoi, T. A Career in Catalysis: Takashi Tatsumi. ACS Catal. 2013, 4, 23-30. [CrossRef]

106. Roth, W.J.; Makowski, W.; Marszalek, B.; Michorczyk, P.; Skuza, W.; Gil, B. Activity enhancement of zeolite MCM-22 by interlayer expansion enabling higher Ce loading and room temperature CO oxidation. J. Mater. Chem. A 2014, 2, 15722-15725. [CrossRef]

107. Mazur, M.; Arévalo-López, A.M.; Wheatley, P.S.; Bignami, G.P.M.; Ashbrook, S.E.; Morales-García, Á.; Nachtigall, P.; Attfield, J.P.; Čejka, J.; Morris, R.E. Pressure-induced chemistry for the 2D to 3D transformation of zeolites. J. Mater. Chem. A 2017, 6, 5255-5259. [CrossRef]

108. Trachta, M.; Bludský, O.; Čejka, J.; Morris, R.E.; Nachtigall, P. From Double-Four-Ring Germanosilicates to New Zeolites: In Silico Investigation. ChemPhysChem 2014, 15, 2972-2976. [CrossRef]

109. Morris, S.; Bignami, G.P.M.; Tian, Y.; Navarro, M.; Firth, D.S.; Čejka, J.; Wheatley, P.S.; Dawson, D.; Slawinski, W.A.; Wragg, D.S.; et al. In situ solid-state NMR and XRD studies of the ADOR process and the unusual structure of zeolite IPC-6. Nat. Chem. 2017, 9, 1012-1018. [CrossRef]

110. Wheatley, P.S.; Chlubná-Eliášová, P.; Greer, H.; Zhou, W.; Seymour, V.R.; Dawson, D.; Ashbrook, S.; Pinar, A.B.; McCusker, L.B.; Opanasenko, M.; et al. Zeolites with Continuously Tuneable Porosity. Angew. Chem. 2014, 126, 13426-13430. [CrossRef]

111. Mazur, M.; Wheatley, P.S.; Navarro, M.; Roth, W.J.; Polozij, M.; Mayoral, A.; Eliasova, P.; Nachtigall, P.; Cejka, J.; Morris, R.E. Synthesis of 'unfeasible' zeolites. Nat. Chem. 2016, 8, 58-62. [CrossRef]

112. Kasneryk, V.; Shamzhy, M.; Opanasenko, M.; Wheatley, P.S.; Morris, S.; Russell, S.E.; Mayoral, A.; Trachta, M.; Čejka, J.; Morris, R.E. Expansion of the ADOR Strategy for the Synthesis of Zeolites: The Synthesis of IPC-12 from Zeolite UOV. Angew. Chem. Int. Ed. 2017, 56, 4324-4327. [CrossRef] 
113. Kasneryk, V.; Opanasenko, M.; Shamzhy, M.; Musilová, Z.; Avadhut, Y.S.; Hartmann, M.; Čejka, J. Consecutive interlayer disassembly-reassembly during alumination of UOV zeolites: Insight into the mechanism. J. Mater. Chem. A 2017, 5, 22576-22587. [CrossRef]

114. Firth, D.S.; Morris, S.A.; Wheatley, P.S.; Russell, S.E.; Slawin, A.M.Z.; Dawson, D.M.; Mayoral, A.; Opanasenko, M.; Polozij, M.; Cejka, J.; et al. Assembly-DisassemblyOrganization-Reassembly Synthesis of Zeolites Based on CFI-Type Layers. Chem. Mater. 2017, 29, 5605-5611. [CrossRef] 